\title{
Mass-transport deposits and fluid venting in a transform margin setting, the eastern Demerara Plateau (French Guiana)
}

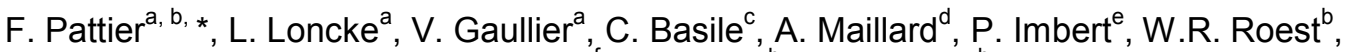 \\ B.C. Vendeville ${ }^{f}, M$. Patriat ${ }^{b}, B$. Loubrieu ${ }^{b}$
}

\footnotetext{
a Univ. Perpignan Via Domitia, CEntre de Formation et de Recherche sur les Environnements Méditerranéens, UMR 5110, 52 Avenue Paul Alduy, F-66860 Perpignan, France

b Ifremer, Centre de Brest, Institut Carnot - Ifremer EDROME, UR Géosciences Marines, BP 70, 29280 Plouzané, France

c ISTerre, UMR-CNRS 5275, Observatoire des Sciences de I'Univers de Grenoble, Université Joseph Fourier, Maison des Géosciences, 1381 rue de la Piscine, 38400 St. Martin d'Hères, France

${ }^{d}$ GET-OMP-Université Paul Sabatier, 14 av. E. Belin, 31400 Toulouse, France

e Total CSTJF, Avenue Larribau, 64000 Pau, France

f UMR 8157 - Géosystèmes, U.F.R. des Sciences de la Terre, Université des Sciences et Technologie de Lille 1, Bâtiment S.N.5, Cité Scientifique, 59655 Villeneuve d'Ascq Cedex, France
}

*: Corresponding author: F. Pattier, tel.: +33468662059 ; fax: +33468661747 ;

email address : france.pattier@univ-perp.fr

\begin{abstract}
:
The eastern Demerara Plateau offshore French Guiana was surveyed in 2003 during the GUYAPLAC cruise (multibeam bathymetry and acoustic imagery, 6-channel seismic reflection and $3.5 \mathrm{kHz}$ echosounding). The data show the "post-transform" Cenozoic that the series located on the outer part of the plateau (below c. $2000 \mathrm{~m}$ ) contain at least twelve stacked mass transport deposits (MTDs) that have recorded a history of large-scale slope failure, as well as two main normal fault sets that provide possible pathways for upward fluid migration through the series, reaching at high as the uppermost MTDs. Seabed data show that the area above the failures is characterized by circular-to-elongate (slope-parallel) depressions interpreted as fluid seeps (pockmarks), some of them have been modified by along slope currents. We suggest that the development of the MTDs to results from the combinaiton of the presence of fluid overpressure at depth the geometry of the margin's deep structure, in particular the existence of a 'free borderlateral border' on the outermost plateau. Our results also emphasise the role of stratigraphic décollements within the Cenozoic series.
\end{abstract}

\begin{abstract}
Highlights
- Cenozoic succession of the Demerara Plateau contains a complex of at least 12 MTDs. Sedimentary undulations and circular to elongated depressions occur on the seafloor. Faults provide fluid migration pathways through the MTDs (biogenic or thermogenic). Detachments occur on stratigraphic horizons that outcrop along the continental slope. Fluid overpressures and the distal transform free border seem to control MTD dynamics.
\end{abstract}

Keywords: Fluid ascent ; Pockmarks ; MTDs ; Transform margin ; Demerara Plateau

\section{Introduction}

Transform margins represent about $30 \%$ of passive margins around the world (Mascle, 1976, Mascle and Basile, 1998 and Mercier De Lépinay et al., 2012). These margins are characterized by high bathymetric gradients along the continental slope 
and by their abrupt ocean-continent transition, inherited from the near vertical transform fault zone along which opening occurred (Basile et al., 2013).

Up to now, studies have focused essentially on the tectonic evolution and the structure of transform margins (Gouyet, 1988; Mascle and Basile, 1998; Greenroyd et al., 2008a and b; Antobreh et al., 2009). Particularly, numerous studies were dedicated to the Agulhas and the Ivory Coast transform margins, in the 1980's (Dingle, 1977, 1980; Dingle and Robson, 1985; Parsiegla et al., 2009) and the 1990's (Mascle et al., 1998; Basile et al., 1998), respectively.

Surface sedimentary processes and the role of fluids in the evolution of these margins have been studied less. The post-Pliocene Agulhas Slump (South Africa) (750 km long, $106 \mathrm{~km}$ wide, with a volume of over $20000 \mathrm{~km}^{3}$ ), was described by Dingle (1977). This slump could relate to motion along two major seismically active fault zones (the Cape Fold Belt and the Agulhas marginal fracture zone) (Dingle, 1977). Other recent studies have shown a link between the presence of large mass movements and the presence or absence of a marginal ridge, notably along the Ivory Coast transform margin (Delayen et al., 2011). The prominence of such bathymetric high that typically bounds transform margins, may have an influence on slope stability (Delayen et al., 2011).

Fluids along transform margins are mainly described in active tectonic settings, such as the Gulf of California or the Marmara basin (Aiello, 2005; Géli et al., 2008; Zitter et al., 2008). These studies have evidenced important occurrences of fluid escapes of thermogenic or biogenic origin. Mantle-derived fluids have even been found in the Marmara basin (Géli et al., 2008; Zitter et al., 2008; Tryon et al, 2010; Burnard et al, 2012). Rising fluids are generally guided toward the surface by active faults or lateral high-permeability conduits and are therefore concentrated along the edges of 
transform basins. In passive transform settings, no studies focusing on fluid escapes have been carried out despite the fact that fluid ascents probably occur there, as is suggested by recent hydrocarbon discoveries made offshore transform margins (e.g., the Jubilee oil field off the Ghanean Coast, and the Zaedyus discovery off French Guiana).

Offshore Guiana, several studies have been realized. They described the French Guiana margin as a transform margin with no marginal ridge (Basile et al., 2013). Numerous MTDs and pockmarks along this margin are present (Loncke et al., 2009; Gaullier et al., 2010; Loncke et al., 2010). The objectives of this work are to determine the causal relationship between subsurface fluid circulation and sediment mass failure along the French Guiana passive transform margin, as well as to specify their role in the evolution of this area. Such a study is crucial for understanding the specificities of methane ascents in these settings and to better constrain the risks associated with the associated fluid overpressure.

\section{Regional setting}

\section{Geodynamic setting and stratigraphy}

The study area is located in the western Equatorial Atlantic Ocean, offhore French Guiana (Figure 1A). The Demerara Plateau is a prolongation of the wide continental shelf (Figure 1A). This Plateau is $380 \mathrm{~km}$ long, $220 \mathrm{~km}$ wide and ranges in depth from 200 to $4500 \mathrm{~m}$. It is delineated by a steep continental slope (slope reaching $15^{\circ}$ to the North) representing the continent-ocean transition.

Prior to the opening of the Equatorial Atlantic, the Demerara Plateau was attached to the Guinean Plateau of the conjugate west African margin (Benkhelil et al., 1995; Erbacher et al., 2004) (Figure 1B). The margin formed during two successive stages: 
(1) During the Early Jurassic, the western edge of the Demerara plateau formed as a divergent segment during the opening of the Central Atlantic Ocean (Klitgord and Schouten, 1986; Gouyet, 1988; Unternehr et al., 1988); (2) at the end of the Early Cretaceous, the Guinean Plateau and the northern and eastern borders of the Demerara plateau separated during the opening of the Equatorial Atlantic Ocean in a strike-slip regime along a main transform zone (Gouyet, 1988; Unternehr et al., 1988; Greenroyd et al., 2008a et b). Transform activity ceased in the Upper Albian (Gouyet, 1988; Mosher et al., 2005; Basile et al., 2013). The deformation history along the Demerara Plateau was described by Gouyet (1988), Greenroyd et al. (2008b) and Basile et al. (2013). Along the eastern edge of the Demerara plateau, the main tectonic structures are NNW-SSE-trending normal faults related to rifting. On its northern edge, WNW-ESE to NW-SE trending acoustic basement ridges, folds and thrusts have been interpreted as transform-related structures (Figure 1, Gouyet, 1988; Basile et al., 2013). During the lower Paleogene, the eastern Demerara plateau was tilted seaward, probably as a result of the onset of the Amazon fan and related sedimentary loading on the oceanic crust off Demerara (Basile et al., 2013; Greenroyd et al., 2008b). There is no clear marginal ridge (Basile et al., 2013).

Post-transform sedimentation on the Demerara plateau (post-Albian, Figure 2) consists of successive sedimentary wedges prograding from the continental shelf, with a maximum total thickness of 4 to $5 \mathrm{~km}$ near the shelf (Gouyet, 1988)(Figure 2). Black shales were deposited during the Cenomanian, shaly sediments during the Upper Cretaceous and calcareous sediments during the Paleogene (Gouyet, 1988). The Amazon system developed during the last 10 Ma (Milliman et al., 1975) and, along with the Orinoco and Maroni rivers, has resulted in sediments that become 
more terrigeneous with time. The ODP Leg 207 revealed a shale-dominated sedimentation during the Neogene (since $16 \mathrm{Ma}$; Mosher et al., 2007).

The seismic stratigraphy used for this zone is provided by the calibration of the GUYAPLAC seismic data (Loncke et al., 2010; Basile et al., 2013) with the G2 industrial well site published by Gouyet (1988) and that is now available with more details in the public domain (Figure 3, modified from Basile et al., 2013).

The sedimentary cover along the eastern Demerara plateau was deposited above the upper Albian post-transform unconformity (Red in Figure 3) that caps deformed Upper Cretaceous and older rocks. Above the upper Albian unconformity reflector, the following three reflectors individualizing three units, can be found (Figure 3):

- R4 bounds the base of Unit C. This unit corresponds to the upper Cretaceous, which is poorly reflective, especially in its lower part, where the transparent seismic facies corresponds to the Cenomanian-Turonian Black shales; This unit is made of sandy claystones and claystones.

- R3 bounds the base of Unit B,w hich comprises four sub-units: (1) a well-bedded and reflective Paleocene, (2) the base of Eocene having a transparent seismic facies, (3) a the more transparent Oligocene, and (4) the lower Miocene, characterized by diffractions hyperbolaes. This unit is made mainly of clayed chalks and oozes;

- R1 marks the base of Unit A. This unit shows high-amplitude continuous reflectors and corresponds to the youngest shale sediments (the upper Neogene and Quaternary) synchronous to those deposited in the Amazon and Maroni.

\section{Physiography and surface processes}


The Demerara Plateau presents a gentle surface slope but its boundaries are abrupt. Basile et al. (2013) divided the Demerara Plateau into four physiographic domains, on the basis of seismic data. This partition is also expressed by the slope values observed on bathymetric data (Figure 4A): (1) the upper plateau (slope value $\left.1^{\circ}\right),(2)$ the intermediate plateau (slope value $3^{\circ}$ ), (3) the lower plateau (slope value $1^{\circ}$ ), and (4) the continental slope (slope value on average $12^{\circ}$, with a maximum value reaching $20^{\circ}$ ) (Figure 4B and $\mathrm{D}$ ). The boundary between the upper plateau and the intermediate plateau is defined by a bathymetric slope break (referred to as a bathymetric scarp in Figure 5) that corresponds to a major sediment slope failure headscarp (see Loncke et al., 2009 and next sections).

The continental slope shows contrasting slope values between the northern segment (i.e., the transform boundary, having an average slope value of $15^{\circ}$ ) and the southern segment (i.e., the divergent boundary, having an average slope value of $4^{\circ}$ )(Figure $4)$.

The seabed of the Demerara Plateau is characterized by a segmented morphology, low slope gradients, a rough surface (undulations trending perpendicular to the slope direction) and a field of pockmarks (Loncke et al., 2009; Gaullier et al., 2010; Loncke et al., 2010). Recent studies partly based on the dataset presented later in this article show that slumps initiated along the main slope of the Demerara plateau. In particular, the recent sedimentary cover of the Demerara plateau offshore French Guiana was utterly destabilized, as has been recorded by numerous stacked transparent masses corresponding to large Mass Transport Deposits (Loncke et al., 2009; Gaullier et al., 2010; Pattier et al., 2011). Giant slumps affecting Oligocene-toRecent sediments have been described in the northwesternmost part of the 
Demerara plateau, offshore Suriname (O'Regan and Moran, 2007; Ingram et al, 2011).

Finally, French Guiana is bounded by several large rivers, the most important of which are the Amazon River to the South, the Maroni River at the Guiana-Suriname border, and the Orinoco to the North. The French Guiana coast is characterized by a muddy northwestwards longshore drift. Mud banks are fed mainly by Amazon river outwash plume (Pujos and Froidefond, 1995). During the retroflection phenomenon of the North Brazil Current, pelagic suspension (on the surface and at the bottom) seasonally invades the continental shelf (Pujos and Froidefond, 1995) (Figure 1). Three major deep-water masses characterize the oceanographic setting along the study area (Figure 1): (1) the SE-NW oriented AntArctic Intermediate Water (AAIW) at $\sim 800-900 \mathrm{~m}$ water depth, (2) the NW-SE oriented North Atlantic Deep Water (NADW) centered at $\sim 2500 \mathrm{~m}$ to $4300 \mathrm{~m}$ water depth, and associated Atlantic Deep Western Boundary Current (DWBC ; $35 \mathrm{~cm} \cdot \mathrm{s}^{-1}$ (Johns et al., 1993)), (3) the SE-NW oriented AntArctic Bottom Water (AABW) at $\sim 4600 \mathrm{~m}$ water depth (Stommel and Arons, 1959; Schmitz and McCartney, 1993; Hogg et al., 1996; Hogg and Owens, 1999; Dengler et al., 2004). Sediment waves, associated with turbidity currents flowing southwards, were described in the Demerara abyssal plain, at $\sim 4000 \mathrm{~m}$ water depth by Gonthier et al. (2002) and Loncke et al. (2009). These bedforms were formed by contourites that transport sediments from the Orinoco river (Gonthier et al., 2002). 


\section{Dataset and methodology}

The GUYAPLAC cruise was carried out onboard the R/V "I'Atalante", as a part of the French EXTRAPLAC Program (Ifremer-IFP-SHOM-IPEV). It surveyed the French Guiana margin and the adjacent Demerara abyssal plain. The dataset comprises (Figure 5): (1) Simrad EM12 multibeam bathymetry and backscatter imagery, (2) 3.5 $\mathrm{kHz}$ subbottom profiles, and (3) 6-channel seismic profiles.

Bathymetric data were processed using the CARAIBES software developed by IFREMER using a $100 \mathrm{~m}$ grid size. By applying a band-pass filter to the multibeam bathymetry data, an interpolated and smoothed version of the original bathymetry surface was created. This smooth DTM was easier to interpret at regional scale. Both grids (smoothed and original) are used in this work.

Seismic data (frequency spectrum 0-110hz) was stacked and migrated using 1500 m. $\mathrm{s}^{-1}$ velocity. This dataset was analyzed by picking main regional reflectors (R1, R2 and R4) calibrated by well data in order to perform seismic stratigraphy.

\section{Architecture of the Demerara plateau}

\subsection{General structure}

Seismic profiles show that the upper Albian unconformity (R4) and post-transform sedimentary cover are tilted seawards (Red in Figure 6A). The upper Albian unconformity is well marked except for the distal part of the Demerara plateau, where it is less regular and difficult to follow precisely (red dotted line in Figures 6A and C). This unconformity usually dips towards the northeast, except when approaching the Demerara plateau transform boundary, where the unconformity appears to have been uplifted and dips southwestwards. There, the continental slope is made of pre- 
Albian series. It is steep and eroded (Figure 6A). The post-Albian sedimentary cover also dips seaward. Some horizons crop out along the eroded continental slope. The Upper Albian unconformity is located at $\sim 3,5$ stwtt in depth in the upper plateau (Figure 6B). This surface then deepens regularly until the intermediate plateau (5.5 to 6 stwtt in depth). A seaward inflexion is observed on seismic data between the upper and intermediate plateaus (Figure 6A).

Figure $6 \mathrm{C}$ is an isopach map of the sedimentary overburden overlying the Albian unconformity, made using a mean seismic velocity for the overburden of $\sim 2 \mathrm{~km} . \mathrm{s}^{-1}$. This isopach map shows that the thickness of the sedimentary rocks decreases sharply along the upper to intermediate plateau boundary (marked on the seafloor by the bathymetric scarp discussed in next sections, in red in Figure 6) from 1500 to $1000 \mathrm{~m}$ (Figure 6B). Units A and B are not laterally continuous. Indeed, these units are affected by a slide complex that destabilized the sedimentary cover over more than $80 \mathrm{~km}$ in length and $500 \mathrm{~m}$ in thickness (Figure 6A), as described in the next section.

\subsection{Mass failure complex and associated MTDs}

\subsubsection{Mass failure complex}

The Cenozoic sediments of the Intermediate to outer Plateau contain a mass failure complex composed of multiple MTDs (Figures 6A, 7A and 8A). The complex covers a total area of $12000 \mathrm{~km}^{2}$ and affects a volume of $4250 \mathrm{~km}^{3}$. The basal décollement surface of this complex (Dotted blue in Figures 6A, 7A and $8 \mathrm{~A}$ ) seems to have initiated in series that are mainly Paleocene in age (unit B). The uppermost limit of the mass failure complex (main headscarp) corresponds to the already defined 
NNW-SSE bathymetric scarp (Figure 5), marked by a normal fault (Figures 6A, 7A and $8 \mathrm{~B}$ ) that corresponds to the boundary between the upper stable plateau and the intermediate destabilized plateau. This headscarp reveals recent activity visible even on subsurface and seismic data (Figure 6).

Upslope, near the bathymetric scarp (mass failure complex headscarp), the mass failure complex has variable thicknesses: northwards it is extremely thin $(\sim 100 \mathrm{~m})$ and southwards it reaches $650 \mathrm{~m}$ in thickness (Figures 6A and 7B). Going distally, the sediment thicknesses increase radially, thus reaching $400 \mathrm{~m}$ towards the Demerara transform boundary and even 650 m-towards the Demerara divergent boundary. Along the northern transform Demerara continental slope (marked on seismic data by a slope having no sediments (Figures $6 \mathrm{~A}$ and $7 \mathrm{~B}$ ), sediment thicknesses decrease sharply from 350 to $0 \mathrm{~m}$, allowing the successive décollement layers to crop out (Figure 6A). The abyssal plain shows numerous MTDs (Pink in Figures $6 \mathrm{~A}$ and 7 ) that could not be dated and that correlates most likely with the mass failure complex. Along the southern divergent Demerara boundary, where the continental slope is smoother, the mass failure complex extends into the abyssal plain (Figure 7A).

Seismic reflectors within the failure complex are sparse but we were able to recognize and map at least twelve different MTDs (Figure 8A). Twelve is a minimum number of MTDs considering the limitations in distinguishing one MTD from another (resolution problems). The largest MTDs can reach $600 \mathrm{~m}$ in thickness and the smallest that we could define is less than $100 \mathrm{~m}$ thick. These MTDs are systematically characterized by irregular and erosive bases (Figure 8). Sometimes, clear reflectors could be mapped within these MTDs. When present, they are 
deformed by compressional ridges (Figure 8C). In most cases, MTDs appear to be nearly acoustically transparent, structureless bodies (Figure 8). Some sparse reflectors could sometimes be observed within MTDs but we never observed clear internal compressional deformation in distal areas (Figure 8D). This characteristic suggests that these MTDs correspond to intensively deformed, if not even liquefied, mass-wasting deposits. Likely, these MTDs originated as slumps and slides that progressively evolved into a range of rafts, structureless bodies or even debris-flow deposits (as is suggested in Mulder and Cochonat's classification, 1996).

In the northern part of the study area (Demerara Transform segment), at least eight MTDs are visible. The oldest (MTD 01 in yellow) affecs the Paleogene (Unit B), whereas the youngest events (MTD 02 in purple, MTD 04 in green, MTD 08 in pink and MTD 09 in blue) have remobilized Unit A sediments (Figures 6 to 8). Upslope an episode of hemipelagic draping is visible between the first event (MTD 01 in yellow) and the second event (MTD 02 in purple) (Figure 8.B). In this area, the last 400 meters of sediments are bedded and apparently poorly remobilized near the mass failure complex headscarp (Figure 8B).

In the southern part of the mass failure complex (Demerara divergent segment), five failure events are recorded. The oldest events (MTD 03 in blue, MTD 05 in orange, MTD 08 in pink and MTD 11 in green) are difficult to correlate with the stratigraphic column provided by the G2 well data. However, the last event (MTD 12 in brown) affects Unit A sediments (Figure 8C).

\subsubsection{Post-MTDs sedimentation}

The post-MTD complex sedimentary cover is diachronous and therefore highly heterogeneous in thickness (Figure 9). 
Along the Northern Demerara plateau (transform segment), this body thickens upslope (reaching 400 meters near the main bathymetric slope failure). It thins along the intermediate plateau, then thickens further downslope $(350 \mathrm{~m})$. The decrease in thickness along the intermediate plateau correlates with an important high within MTD 12. The upslope thicknesses could be related to slow and regular reactivation of the main failure fault that may have allowed for progressive sediment thickening with no clear downslope movement.

Along the Southern Demerara plateau (divergent segment), the post-MTD body remains thin, even near the main bathymetric slope failure (from 0 to $100 \mathrm{~m}$ ). This body thickens gradually towards the continental slope and the abyssal plain reaching maximum values of $1100 \mathrm{~m}$ at the mouth of the main active canyons (see Loncke et al., 2009 for description of the canyon activity). The fact that this post-MTD body is extremely thin upslope is related to the recent emplacement of MTD12 that remobilized young sediments.

\subsection{Faults}

The sedimentary cover is highly faulted by normal faults upslope and beneath the mass failure complex (Figure 10). The Demerara plateau shows two fault families.

The first fault family affects Units $A$ and $B$, dominated by fine-grained clay and chalk (Figure 3) (in yellow, Figure 10). Fault spacing is around $800 \mathrm{~m}$ and faults affect sediment thicknesses varying from $0.4 \mathrm{~ms}$ to $0.8 \mathrm{~ms}$. This first family is not visible downslope of the headscarp that marks the upslope limit of the MTD complex. The faults are visible either on NW and NE seismic profiles, and only affect Unit B and partly Unit A. Therefore, we interpreted these faults as part of a polygonal fault 
system related to internal dewatering soon after deposition or during burial history (see Cartwright et al., 2011 for complete review on polygonal fault intervals).

The second fault family affects the entire sedimentary cover (Units A, B and C), composed of clay, chalk and sandy claystones (Figure 3) (in red, Figure 10). The fault spacing is $4 \mathrm{~km}$ on SW-NE profiles and 1 to $2 \mathrm{~km}$ on NW-SE profiles. The faults affect sediments whose thickness varyies from $0.8 \mathrm{~ms}$ to $1.2 \mathrm{~ms}$, and some faults reach the seafloor (Figure 10). These faults mostly root at deep and offset the Albian unconformity (Figure 10). The fault offset decreases upwards, suggesting that they result from differential compaction of deep compressible sediments. This second family has variable geometrical relations with the mass failure complex (see next section Figure 12C). Some faults are cut by the complex (see next section, Figure 14C). This geometrical relationship suggests that the formation of the second family interval was partly predates that of the mass failure complex. However, some of these faults affect the mass failure complex (see next section Figure 12C) suggesting they were reactivated (continuous differential compaction). 


\section{Correlation between deep and surface structures}

We have identified on the Demerara plateau seventy depressions on the sea floor (Figure 11A). The highest density of these depressions is localized on the intermediate plateau. The depressions are circular or elongate (Figure 11B). When elongate, they look like flute-mark depressions trending SE. This elongation may be related to the existence of a southeastwards deep bottom current (DWBC) (Figure 1). The distribution of these depressions is heterogeneous and subdivided into several fields (Figure 11A). The dimensions of the depressions are variable. They have an average width of $540 \mathrm{~m}$ (ranging from $100 \mathrm{~m}$ to $2 \mathrm{~km}$ ), and an average length of 1.4 $\mathrm{km}$ (ranging from $100 \mathrm{~m}$ to $10 \mathrm{~km}$ ). Their depth below the seafloor ranges from $5 \mathrm{~m}$ to $90 \mathrm{~m}$ with a mean of $26 \mathrm{~m}$. Smaller depressions, not visible on the $100 \mathrm{~m}$ resolution DTM may also be present.

The backscatter imagery shows that some of these depressions are highly reflective (40\%) (Figure 11C to F), suggesting they are filled with coarse deposits. This high reflectivity could correspond to lithified sediments (eroded or sandy domains) or to authigenic carbonate crusts, typically associated with active pockmarks (Gay et al., 2006; Bayon et al., 2009).

Some of these depressions can be visible on the few seismic and chirp lines crossing their location. In detail, we could distinguish two types of depressions :

- Type A depressions are small (average diameter of $340 \mathrm{~m}$ ), circular and symmetric (Figure 11F). Type A depressions are highly reflective on acoustic backscatter data mainly in their centers (Figure 11F). They look like some pockmarks that are described in the literature (i.e., Hovland, 1989; Loncke et al., 2004; Pilcher and Argent, 2007). Type A depressions are best imaged on $3.5 \mathrm{kHz}$ data. They appear as 
acoustically transparent depressions that cut surrounding reflectors (Figure 12A, B, depressions 1,2, and 3). Some high amplitude reflectors are sometimes observed at the base of these structures (Figure 12, depression 2). On seismic data, these depressions are poorly expressed. They only affect the first seafloor reflecors and are underlined by diffraction hyperbolas. These features are located immediately above MTD highs (mainly MTD 04, MTD 08, MTD 10 and MTD 12) (Figure 13C and D, depressions 1, 2, and 3).

- Type B depressions are elongate and asymmetric (Figure 12D and E). These form the largest and deepest depressions (with a minimum average width of $400 \mathrm{~m}$ and length of $800 \mathrm{~km}$ ). They present a steep northwestern flank (referred to as NW slope, $3^{\circ}$ average, in Figure 13) and a gentler southeastern flank. Some of them have remarkable dimensions (Numbers 5 and 6 in Figure 11B). They reach an average width of $1.5 \mathrm{~km}$, an average length of $6 \mathrm{~km}$ and a mean depth of $50 \mathrm{~m}$. Some Type B depressions present high reflectivity along their steepest northwestern flank only, others along their steep flank and center (Figure 11D and E). Some depressions in the middle of the Demerara plateau seem to form a SW-NE downslope alignment along a furrow (Figure 11). Type B depressions appear on $3.5 \mathrm{kHz}$ data as asymmetric (Figure 12B, Depression 4 and Figure 14A, Depressions 5 and 6). A steep flank systematically characterizes the northwestern border of these features. The southeastern border is smoother. The steepest flank is acoustically transparent. This echo-facies may be related to either the presence of a non-penetrative body or to a seismic wipe-out due to high gas contents. In any case, this flank shows a sharp contrast with the more bedded and sedimented southeastern flank. Along these smooth flanks, transparent debris-flow like deposits sometimes interfinger with 
bedded deposits (Figure 14A, Depression 5). On seismic data, these depressions only affect the first seafloor reflector. No diffraction hyperbolas could be observed. Type B depressions are systematically emplaced on the southeastern edge of underlying nearly outcropping MTD highs and sometimes above faults (Figure 14) (mainly MTD 04, MTD 08 and MTD 12) (Figure 12D, Depression 4 and Figure 14B, depressions 5 and 6). It is possible therefore that the transparent acoustic facies identified on $3.5 \mathrm{kHz}$ correspond to MTD outcrops.

On seismic data, we investigated the depression aligned along the SW-NE axis of a furrow (Figures 12B, D). Unfortunately, only two seismic lines intersect this bathymetric structure. It appears that this downslope alignment along a furrow is emplaced above the southeastern face of an MTD high whose exact extent could not be mapped (MTD 10; Figure 12D, interpreted as a raft).

\section{Discussion}

\subsection{Origin of elongated depressions and implications}

\subsubsection{Are these depressions pockmarks?}

There are two types of depressions: Type A depressions are small, circular and look like pockmarks. Type B depressions are larger and elongate (Figure 15).

Type A depressions intersect seismic reflectors and show internal transparent acoustic facies. This is typical of active gas escapes or blow outs associated with pockmarks (Hovland, 1989; Foland et al., 1999; Gay et al., 2006). Important surface reflectivity also characterizes these depressions - an occurrence that is typical of 
methane-derived carbonates that form in pockmarks (Loncke et al., 2004; Gay et al., 2006; Bayon et al., 2009). Seismic data indicate that these pockmarks are systematically emplaced at the top of nearly outcropping MTD highs. These highs may guide fluids to the surface (Figure 15).

Type B depressions are in turn elongate and asymmetric, having a steep northwestern flank and a gentler-dipping southeastern flank. There look like giant flute casts (Allen, 1982) and likely formed by the DWBC deep current. Their northwestern steep flank is characterized on $3.5 \mathrm{kHz}$ data by transparent acoustic facies, which we interpret as either eroded or gas-rich sediments. Their gentler southeastern flank shows bedded acoustic facies on $3.5 \mathrm{kHz}$ data. These features are characterized, for part of them (the largest depressions), by high reflectivity, mainly along their steepest flank and sometimes within their gentle flank. These structures are systematically emplaced on the southeastern flank of nearly outcropping MTD highs, sometimes above faults (Figures 14D and 15). We assume that the Type B depressions correspond to less active or older pockmarks, elongated by deep currents (as offshore Norway for example, Bøe et al., 1998) and draped by recent sediments. They probably initiate above MTDs as Type A pock-marks, allowing progressive MTD to crop out. Then, it is likely that these outcropping highs form an obstacle that build downstream from that location. If so, these depressions can be considered as giant pockmarks, having diameters larger than $250 \mathrm{~m}$ (Foland et al., 1999; Pilcher and Argent, 2007).

Some pockmarks present in the center of the Demerara plateau seem to form a SWNE downslope alignment along a furrow (Figures 11 and 12C and D). Our data set 
shows that this bathymetric alignment may correspond at depth to the lateral boundary of a MTD high (MTD 12) that may form a sort of raft whose boundaries may guide fluids to the surface.

\subsubsection{Origin of fluid escapes and possible migration pathways}

\section{Origin of fluids}

\section{Compactional origin (water)}

Two compactional origins are envisaged (Blue arrows, Figure 16). (1) Fluids (i.e., mainly water) could originate from compaction and associated dewatering of the mass failure complex. Indeed, pockmarks are located only above the MTDs and especially above MTD highs (Bayon et al 2009; Garziglia et al, 2010; Plaza-Faverola et al, 2010; Reiche 2011); and (2) Fluids could be released within the sedimentary cover during the onset of a polygonal fault system (Blue arrows, Figure 16) (Gay and Berndt, 2007; Cartwright, 2011). In our study area, we suggest the presence of one family of polygonal faults (section 4.3).

\section{Biogenic origin (post-Albian series)}

Organic-rich surface sediments are subjected to bacterial reduction that produces biogenic methane (pink arrows, Figure 16). The deep Cenomanian black shales were sampled during ODP 207 leg. Analyses showed that in situ microbial activity was still active within these layers (Meyers et al., 2004). O'Regan and Moran (2007) suggest that some part of the black shale derived methane may migrate toward the surface in the northern edge of the Demerara plateau. Tus, most of the potential organic-rich, post Albian sediments seem to be able to provide biogenic gases to the surface. 


\section{Thermogenic origin: Deep pre-Albian reservoirs and source rocks}

Evidence for migration of presumably thermogenic hydrocarbon gases has been described in the ODP-207 Leg (Meyers et al., 2004). Furthermore, recent discoveries have revealed hydrocarbon potential along the French Guiana margin (Zaedyus well). The pre-Albian Cretaceous and even Jurassic series, considering their depth of burial, could be the location of methane and oil production. The average oil window, assuming a $25-35^{\circ} \mathrm{C} / \mathrm{km}$ geothermal gradient, is located between 3 and $4,2 \mathrm{~km}$ under the seabed (Figure 16). Furthermore, the pre-Albian series are affected by compressional deformation (e.g., thrusts, anticlines; Basile et al., 2013) that may focus the fluid escape under the Demerara plateau (Figure 16).

\section{Fluid pathways}

To explain the existence of water or methane seepage on the seafloor, we can consider several possible permeable conduits and fluid pathways (Figure 16):

\section{$\underline{\text { Role of faults }}$}

Polygonal faults may act as permeable zones when compaction begins, but they can be cemented later (Gay and Berndt, 2007; Cartwright, 2011). Some authors (Gay and Berndt 2007) consider that these faults can be regularly re-activated and reopened by sediment loading or by tectonic activity. In our study area, the first family of faults (Yellow in Figure 16) only affects Eocene to Oligocene sediments. None of these faults reach the seafloor, nor are they found below the pockmark field. 
In turn, the second fault family (Red in Figure 16) affects the entire sedimentary package, from the unconformity up to the seafloor (upslope the pock-mark field). These faults may channel deeper biogenic or thermogenic fluids up to the surface (Pink and green arrows in Figure 16). Below the pockmark field, these faults do not reach the seafloor. They vanish at the base or within the MTD complex. Some faults reach the most recent MTDs. It is thus possible that thermogenic gases (Green arrows), biogenic gases (Pink arrows) and/or compactional water (Blue arrows) reach the mass failure complex, and accumulate within or below some MTDs (depending on their internal porosity and permeability).

\section{The role of MTDS}

The spatial correlation between fluids and MTDs is common in the world but remains always difficult to decipher. Several authors pointed-out that important slides could be related to fluid overpressure at depth (Mourges and Cobbold, 2003; Cobbold et al., 2004; Bayon et al., 2009; Cobbold et al;, 2009; Mourgues et al., 2009; Lacoste et al., 2011). In such settings, fluid escape structures are frequently observed at the surface of destabilized masses (Bayon et al., 2009; Cobbold et al, 2009; Lacoste et al., 2010, 2011) as a result of mass movement and the associated evacuation of overpressure at depth. This type of fluid escape is usually best focused along initiation faults and distal compressional toes (Cobbold and Rodrigues, 2007; Lacoste et al., 2011). In the study area, the mass failure complex is made of several stacked MTDs showing no internal structures. These MTDs may be interpreted as structureless debris-flow deposits originating from sliding or slumping processes (as proposed in Mulder and Cochonnat's classification, 1996). The main pock-mark field lies above 
this complex. In such case, it is difficult to predict what was the influence of these MTDs on fluids: (1) If their internal permeability is low, they may have acted as barriers for deeper fluid ascents. If so, we must consider that all observed pockmarks originated from surface biogenic degradation of recent organic matter, but also that deeper potential fluid ascents (guided by the second fault family) may have accumulated at the base of these MTDs; and (2) Alternatively, these MTDs may, if their internal permeability is high enough, have acted as surface reservoirs for fluids (either biogenic or thermogenic) rising from deeper levels. If this is the case, fluids could escape most easily towards the seafloor where the post-MTD sedimentary cover was the thinnest (above MTD highs). Finally, it is also possible that these MTDs trapped important quantities of water during their emplacement. If so, these fluids could be later expelled to the seafloor during compaction. Again, the easiest pathways should be the areas where the sedimentary cover is the thinnest, i.e., above MTD highs.

\section{$\underline{\text { The role of permeable layers }}$}

Within the post Albian cover, several permeable regional lateral conduits under low permeability layers may exist and allow for lateral fluids flow. These lateral conduits all dip seaward and crop out along the continental slope ("free border" in Figure 16). The sedimentary cover thins towards the continental slope, which means that lithostatic pressure decreases seaward. It is possible that, as was proposed by O'Regan \& Moran (2007), lateral fluid flow occurs along these conduits and, possibly, that fluids escape towards the continental slope. Also, some of these fluids may be guided to the surface by faults intersecting these horizons (Figure 16). 
From a stratigraphic point of view, there is too little information to constrain these potential lateral conduits; only the main sedimentological packages have been characterized using the drilling reports of Well G2 (Figure 3). However, we believe that several lateral fluid conduits could occur. For example, and despite the poor stratigraphy knowledge we can propose the following conduits :

- At the base of unit B (Paleocene) (Figure 3), where the sediments are composed of clayey chalks (Mosher et al., 2007). In the ODP 207 well results, increased methane concentrations (25 000 - 30000 ppmv) were indeed detected at the base of this unit that probably acts as a low-permeability layer.

- At the base of MTDs;

- Above the black shales that appear to be permeable (Meyers et al., 2004). These black shales were described as under-consolidated (O'Regan and Moran, 2007) and are overlain by claystones that probably are less permeable.

\subsection{Origin of MTDs}

The Guianese part of the Demerara plateau is made of transform and divergent segments. This plateau underwent significant and repetitive mass movements during the Cenozoic and has less sediments. These mass failures initiated far inland on the Demerara plateau, where slope values or gradients are low, suggesting that there is a structural control and/or retrogressive evolution of slides from the steep continental slope toward the inner plateau through time.

Different factors could have participated in the initiation of the mass failure complex:

1. It is possible that these MTDs are related to massive hydrate dissociation as proposed by Ingram et al. (2011). Indeed, the Demerara Plateau is deep enough to 
form frozen gas hydrates within shallow horizons near the seaf loor (Kvenvolden, 1995). The ice-house to green-house transition (Eocene-Oligocene transition; Séranne, 1999) could be an excellent candidate for initiating failures that include the MTD complex. This hypothesis implies that the base of hydrate stability regularly moved since that time. However, so far, we have not been able to identify a BSR in our data set.

2. Ingram et al. (2011), on the basis of studying an active fault located in the northern part of the Demerara plateau in Suriname, proposed that seismic events could have triggered slumps observed offhore Suriname. But considering the Guiana passive margin setting, it seems difficult to propose that 12 MTDs may be related to such seismic events.

3. Finally it is possible that these events relate to cyclic fluid overpressure that regularly activate décollement planes and allow fluid emissions during and after mass movement. Indeed, several works (i.e., Mourgues and Cobbold, 2003, 2006; Mourgues et al. 2009) show that fluid overpressure under an impermeable layer can drive huge gravity movements (such as in the Niger and Amazon fans). More recently, Lacoste et al. $(2009,2010,2011)$ showed how fluid overpressure is efficient parameter capable of destabilizing retrogressively large sediment series when the series are not laterally buttressed (presence of a free border). A free border greatly enhances the instability power in the presence of fluid overpressure at depth. In the study area, the upslope basal décollement layer corresponds to the Paleocene base known to concentrate high methane concentration and may act as a seal for deeper fluid ascents (O'Regan and Moran, 2007)(Figure 6). This décollement layer crops out along the "transform" continental slope that acts as a "free border" for slope stability. This basal décollement layer is located above the Cenomanian-Turonian black 
shales, known to be a source rock in the area, and described by O'Regan and Moran (2007) as under-consolidated and over-pressured with active bacterial methanogenesis.

We therefore propose, on the basis of our observations that fluid overpressure at depth may have allowed the activation of stratigraphic décollement layers through time. Along the transform segments, the steep continental slope acted, as a free lateral boundary for slope stability along which the potential overpressured detachment layers crop out at the seafloor (Figure 3). Accordingly, the Cenozoic seaward tilt of the Demerara Plateau (Basile et al., 2013) played a major control of the plateau instability by allowing the existence of a seaward "free boundary" and triggering the first instability events. Such setting ("free boundary" + fluid overpressure) is particularly favorable for slide initiation and important lansward retrogressive propagation (Lacoste et al., 2011). Furthermore the black shales are the locus of continuous organic matter degradation and methane was thus continuously created from Cretaceous to present times. The methane may regularly accumulate under the low-permeability Paleocene (unit B) and the later MTD series allowing for cyclic generations of overpressure and slope failures. We believe that such mechanism alone could explain the regular and inland remobilization of a great part of the Demerara plateau. This process may have been amplified during climatic transitions by hydrate dissociation or by seismic activity.

\section{Synthesis and proposed evolutionary scenario}

On the basis of observations and interpretation developed up to now, we propose the following evolutionary scenario for the Demerara plateau (Figure 17): 
(1) The study area underwent an erosion phase during Albian times, as recorded by the post-transform unconformity (Gouyet, 1988; Basile et al., 2013). This erosion phase is attributed to the main uplift related to transform activity. The end of transform activity is marked by the upper Albian unconformity (in red, Figure 17.1).

(2) During the Upper Cretaceous, a succession of anoxic events led to deposition of Cenomanian-Turonian black shales (rich in organic matter) (Wagner and Pletsch, 1999; Friedrich and Erbacher, 2006) (unit C) (Brown in Figure 17.2).

(3) During the Cenozoic, the Demerara plateau was tilted seaward (Figure 17.3) (Basile et al., 2013). The cause of this tilting is beyond the scope of our work, but it could be due to the onset of sediment deposition of the Amazon fan (see Greenroyd et al., 2008b and Basile, et al., 2013 for further discussion). This tilting structured the Demerara plateau by bending the post-transform unconformity and the sedimentary cover seaward (Figure 17.3). From that time on, the continental slope acted as free boundary for sediment deposition and stability of the Cenozoic sedimentary cover.

(4) The lower Paleogene sediments (unit B) draped older sediments, and progressive compaction started with the development of two fault families (Figure 17.4). These fault families are intersected by the first gravity destabilization.

(5) After deposition of the Oligocene sedimentary sequence (upper unit B), a first gravity destabilization (composed by several MTDs) occurred (Figure 17.5). Therefore the first event could be of Miocene age. It is possible that the margin bend between the upper and intermediate plateau, probably inherited from the Guiana seaward tilt, localized this first MTD initiation (or limited upslope retrogressive evolution). Middle Miocene is the age assigned to the slump identified in Leg 207 (Ingram et al., 2011). 
(6) Neogene sediments (Unit A) became more terrigeneous with the onset of the Amazon and Maroni rivers. The second fault family continued to develop during the Lower Neogene. This family cuts through the first MTDs but does not affect most recent MTDs.

(7) Other MTDs (i.e., MTD 12) formed during the Neogene (Unit A) as observed on seismic data (Figure 17.7). MTDs are stacked in the outer portion of the Demerara plateau and or deposited in the abyssal plain. These events cut the downslope part of the second family of polygonal faults.

(8) Finally, the Upper Neogene and the Quaternary (Unit A) are marked by hemipelagic sedimentation (draping MTDs) and the development of pockmarks (Figure 17.8). Hemipelagic post MTD deposition was uneven. Along the Southern part of the main bathymetric scarp, post-MTD sediments are extremely thin as a consequence of the recent emplacement of MTD12. Most pockmarks seem to have been emplaced above MTDs highs (MTDs 04, 08, 12), where post-MTD sedimentation is thin.

\section{Conclusions}

The western Demerara Plateau is a passive transform margin where sediment mass failures and seafloor fluid emissions occurred. However, we observe that MTDs in this area are massive $\left(<4250 \mathrm{~km}^{3}\right)$ and recurrent through time. Seventy circular to elongate depressions, probably corresponding to pockmarks, were identified on the seafloor. Two families faults are described. Three origins for the fluids are possible: compactional, biogenic or thermogenic. Faults, layers and discontinuities are recognized as potential conduits for fluid flow. We propose that fluid overpressure, combined with the potential décollement layers cropping out ("free boundary" effect 
along transform segments) are key parameters in the initiation and development of widespread mass movements retrogressively eroding the Demerara Plateau. Nevertheless, other structural and climatic controls cannot be excluded in having controlled the development of these mass failure complexes. Future high-resolution seismic campaigns will help to further characterize the distribution and activity of fluid ascents and the internal structure of the mass failure complex.

Acknowledgments: The authors would like to thank the French EXTRAPLAC program for providing access to the GUYAPLAC dataset and Ifremer for financing the Ph.D. work of France Pattier. The French Research Program "Actions Marges" is acknowledged for its support of this project. We thank Total S.A. for granting us access to the Well G2 data. We also deeply thank David Mosher and Daniel Praeg for their very useful reviews and comments.

\section{References}

Aiello, I.W., 2005. Fossil seep structures of the Monterey Bay region and tectonic/structural controls on fluid flow in an active transform margin. Palaeogeography, Palaeoclimatology, Palaeoecology 227, 124-142.

Allen, J.R., 1982. Sedimentary Structures: Their character and physical basis. Oxford Elsevier II, 253.

Antobreh, A., Faleide, J., Tsikalas, F., Planke, S., 2009. Rift-shear architecture and tectonic development of the Ghana margin deduced from multichannel seismic reflection and potential field data. Marine and Petroleum Geology 26, 345-368.

Basile C., Maillard A., Patriat M., Gaullier V., Loncke L., Roest W., Mercier de Lépinay M., Pattier F., 2013. Structure and evolution of the Demerara Plateau, 
offshore French Guiana : rifting, tectonic inversion and post-rift tilting at transform-divergent margins intersection. Tectonophysics, Special Issue "Basin Dynamics", Eds. Roure F., Gaullier V., Scheck-Wenderoth M., Basile C., DOI 10.1016/j.tecto.2012.01.010

Basile, C., Mascle, J., Benkhelil, J., Bouillin, J., 1998. 11. Geodynamic evolution of the côte d'ivoire-ghana transform margin: an overview of leg 159 results 1 . Sites The Journal Of 20Th Century Contemporary French Studies 159.

Bayon, G., Loncke, L., Dupré, S., Caprais, J.-C., Ducassou, E., Duperron, S., Etoubleau, J., Foucher, J.-P., Fouquet, Y., Gontharet, S., 2009. Multidisciplinary investigation of fluid seepage on an unstable margin: The case of the Central Nile deep sea fan. Marine Geology 261, 92-104.

Benkhelil, J., Mascle, J., Tricart, P., 1995. The Guinea continental margin: an example of a structurally complex transform margin. Atlantic 248, 117-137.

Bøe, R., Rise, L., Ottesen, D., 1998. Elongate depressions on the southern slope of the Norwegian Trench (Skagerrak): morphology and evolution. Marine Geology 146, 191-203.

Burnard P., Bourlange S., Henry P., Géli L., Tryon M.D., Natal In B., Sengor AMC., Ozeren M.S., Cagatay M.N., 2012. Constraints on fluid origins and migration velocities along the Marmara Main Fault (Sea of Marmara, Turkey) using helium isotopes. Earth and Planetary Science Letters 341-344 (2012) 68-78.

Cartwright, J., 2011. Diagenetically induced shear failure of fine-grained sediments and the development of polygonal fault systems. Marine and Petroleum Geology 28, 1593-1610. 
Cobbold, P.R., Mourgues, R., Boyd, K., 2004. Mechanism of thin-skinned detachment in the Amazon Fan: assessing the importance of fluid overpressure and hydrocarbon generation. Marine and Petroleum Geology 21, 1013-1025.

Cobbold, P.R., Rodrigues, N., 2007. Seepage forces, important factors in the formation of horizontal hydraulic fractures and bedding-parallel fibrous veins ("beef" and "cone-in-cone"). Geofluids 313-332.

Cobbold, P.R., Clarke, B.J. and Løseth, H., 2009. Structural consequences of fluid overpressure and seepage forces in the outer thrust belt of the Niger Delta. Petroleum Geoscience, 15, pp. 3-15

Delayen J., Loncke L., Pattier F., Gaullier V., Basile C., Vendeville B.C., Maillard A., Patriat M., Roest W.R., Mercier De Lepinay M. Et Mascle J., 2011. Distribution et typologie des glissements Gravitaires le long de la marge transformante Côte D'ivoire-Ghana. $13^{\text {ème }}$ Congrès Français de Sédimentologie (ASF), 14-16 nov. 2011, Dijon, Livres des résumés, Publ. ASF, Paris, 68, p. 106.

Dengler, M., Schott, F.A., Eden, C., Brandt, P., Fisher, J., Zantopp, R.J., 2004. Break-up of the Atlantic deep western boundary current into eddles at $8^{\circ} \mathrm{S}$. Nature 432, 1018-1020.

Dingle, R.V., 1977. The anatomy of a large submarine slump on a sheared continental margin (SE Africa). Journal of the Geological Society 134, 293-310. Dingle, R.V., 1980. Large allochthonous sediment masses and their role in the construction of the continental slope and rise off southwestern Africa. Marine Geology 37, 333-354.

Dingle, R.V., Robson, S., 1985. Slumps, canyons and related features on the continental margin off East London, SE Africa ( SW Indian Ocean ). Marine Geology 67, 37-54. 
Erbacher, J., Mosher, D.C., Malone, M.J., al, E., 2004. Proceedings of the Ocean Drilling Program, Initial Reports, 207.

Foland, S.S., Maher, N., Yun, J.W., 1999. Pockmarks along the Californian Continental Margin: implications for fluid flow. Abstract. AAPG Bull 83, 681-706. Friedrich, O., Erbacher, J., 2006. Benthic foraminiferal assemblages from Demerara Rise (ODP Leg 207, western tropical Atlantic): possible evidence for a progressive opening of the Equatorial Atlantic Gateway. Cretaceous Research 27, 377-397.

Gaullier V., Loncke L., Droz L., Basile C., Maillard A., Patriat M., Roest W.R., Loubrieu B., Folens L., Carol F., 2010. Slope Instabilities along the French Guiana Transform Margin from Swath-Bathymetry and $3.5 \mathrm{kHz}$ Echograms. In: Mosher, D.C., Shipp, C., Moscardelli, L., Chaytor, J., Baxter, C., Lee, H. and Urgeles, R. (Eds). Submarine Mass Movements and Their Consequences, 4th International Symposium; Advances in Natural and Technological Hazards Research, 28, DOI 10.1007/978-90-481-3071-9, Springer, The Netherlands, 569-579.

Gay, A., Berndt, C., 2007. Cessation / reactivation of polygonal faulting and effects on fluid flow in the Vøring Basin , Norwegian Margin. Journal of the Geological Society, London 164, 129-141.

Gay, A., Lopez, M., Cochonat, P., Seranne, M., Levache, D., Sermondadaz, G., 2006. Isolated seafloor pockmarks linked to BSRs, fluid chimneys, polygonal faults and stacked Oligocene-Miocene turbiditic palaeochannels in the Lower Congo Basin. Marine Geology 226, 25-40.

Garziglia, S., Sultan, N., Cattaneo, A., Ker, S., Marsset, B., Riboulot, V., Voisset, M., Adamy, J., Unterseh, S., 2010. Identification of shear zones and their causal 
mechanisms using a combination of cone penetration tests and seismic data in the Eastern Niger Delta. In: Mosher, D., et al. (Eds.), Submarine Mass Movements and Their Consequences - Advances in Natural and Technological Hazards Research. Springer 28, 55-65.

Géli, L., Henry, P., Zitter, T., Dupré, S., Tryon, M., Çağatay, M.N., de Lépinay, B.M., Le Pichon, X., Şengör, A.M.C., Görür, N., Natalin, B., Uçarkuş, G., Özeren, S., Volker, D., Gasperini, L., Burnard, P., Bourlange, S., 2008. Gas emissions and active tectonics within the submerged section of the North Anatolian Fault zone in the Sea of Marmara. Earth and Planetary Science Letters 274, 34-39.

Gonthier, E., Faugères, J.C., Gervais, A., Ercilla, G., Alonso, B., Baraza, J., 2002. Quaternary sedimentation and origin of the Orinoco sediment-wave field on the Demerara continental rise (NE margin of South America). Marine Geology 192, 189-214.

Gouyet, S., 1988. Evolution tectono-sédimentaire des marges guyanaise et nordbrésilienne au cours de l'ouverture de l'Atlantique Sud. Ph. D. Thesis, Université de Pau, $374 \mathrm{p}$

Greenroyd, C.J., Peirce, C., Rodger, M., Watts, A.B., Hobbs, R.W., 2008a. Do fracture zones define continental margin segmentation? - Evidence from the French Guiana margin. Earth and Planetary Science Letters 272, 553-566.

Greenroyd, C.J., Peirce, C., Rodger, M., Watts, A.B., Hobbs, R.W., 2008b. Demerara Plateau - the structure and evolution of a transform passive margin. Geophys. J. Int. 549-564.

Hogg, N.G., Owens, W.B., 1999. Direct measurement of the deep circulation within the Brazil Basin. Deep Sea Research Part II 46, 335-353. 
Hogg, N.G., Owens, W.B., Siedler, G., Zenk, W., 1996. Circulation in deep Brazil current, in: The South Atlantic: Present and Past Circulation. Wefer, G., Berger, W.H., Siedler, G., Webb, D.J, Berlin, pp. 249-260.

Hovland, M., 1989. The formation of pockmarks and their potential influence on offshore construction. Quarterly Journal of Engineering Geology, London 22, 131-138.

Ingram, W.C., Mosher, D.C., Wise, S.W.J., 2011. Biostratigraphy of an upper Miocene mass-transport deposit on Demerara Rise, northern South American margin, in: Mass-transport Deposits in Deepwater Settings. Shipp, C., Weimer, P, and Posamentier, H, pp. 475-498.

Johns, W.E., Fratantoni, D.M., Zantopp, R.J., 1993. Deep western boundary current variability off northeastern Brazil. Deep-Sea Research I 40, 293-310.

Klitgord, K.D., Schouten, H., 1986. Plate kinematics of the central Atlantic, in: Vogt, P.R., Tucholke, B.E. (Eds.), The Western North Atlantic Region. Geological Society of America, Boulder, pp. 351-378.

Kvenvolden, K.A., 1995. A review of the geochemistry of methane in natural gas hydrate. Organic Geochemistry 23, 997-1008.

Lacoste, A., Vendeville, B.C., Loncke, L., 2011. Influence of combined incision and fluid overpressure on slope stability: Experimental modelling and natural applications. Journal of Structural Geology 33, 731-742.

Lacoste, A., Vendeville, B.C., Mourgues, R., Loncke, L., Lebacq, M., 2010. Gravitational instabilities triggered by fluid overpressure and downslope incision - Insights from analytical and analogue modelling. Journal of Structural Geology. 
Lacoste, A., 2009. Glissements de terrain, surpressions de fluide et incisions : caractérisation géologique et modélisation. Exemple du complexe de Waitawhiti, Nouvelle-Zélande. Pd. D. Thesis, Université de Lille 1, 214p

Loncke, L., Mascle, J., and the Fanil scientifc parties, 2004. Mud volcanoes, gas chimneys, pockmarks and mounds in the Nile deep-sea fan (Eastern Mediterranean): geophysical evidences. Marine and Petroleum Geology 21, 669-689. DOI : 10.1016/j.marpetgeo.2004.02.004

Loncke, L., Droz, L., Gaullier, V., Basile, C., Patriat, M., Roest, W., 2009. Slope instabilities from echo-character mapping along the French Guiana transform margin and Demerara abyssal plain. Marine and Petroleum Geology 26, 711723.

Loncke, L., Gaullier, V., Basile, C., Maillard, A., Patriat, M., Roest, W., Vendeville B., 2010. Deep to surface processes of the French Guiana transform margin, Eastern Demerara plateau. II Central and North Atlantic Conjugate Margins Conference, Lisbon, Portugal, 29th September-1st October 2010. "Rediscovering the Atlantic: New Ideas for an old sea", Extended abstracts, Eds. R. P. Dos Reis and N. Pimentel, 147-151, ISBN: 978-989-96923-1-2.

Mascle, J., 1976. Le golf de Guinée: un example d'évolution de marge atlantique en cisaillement. Mémoires de la société Géologique de France, 128, 104 pp

Mascle, J., Basile, C., 1998. Marges continentales transformantes / Continental transform margins. C. R. Acad. Sci. Paris, Sciences de la terre et des planètes / Earth \& Planetary Sciences 326, 827-838.

Mascle, J., Lohmann, G.P., Moullade, M. (Eds. ), 1998. Proceedings of the Ocean Drilling Program, Scientific Results 159: College Station, TX (Ocean Drilling Program). 
Mercier De Lépinay M., Basile C., Roest W. R., Patriat M., Loncke L., Gaullier V., Maillard A., De Clarens P., 2012. Global inventory of transform continental margins: physiographic attributes and controlling parameters. 34th International Geological Congress (IGC-2012): « Unearthing Our Past And Future Resourcing Tomorrow », Brisbane, Queensland, Australia, 5-10 August 2012, Proceedings CD, ISBN 978-0-646-57800-2, p. 2693, \#2713.

Meyers, P.A., Forster, A., Sturt, H., 2004. 9. MICROBIAL GASES IN BLACK SHALE SEQUENCES ON THE DEMERARA RISE. Proceedings of the Ocean Drilling Program 207, 1-18.

Milliman, J.D., Summerhayes, C.P., Barretto, H.T., 1975. Quaternary sedimentation on the Amazon continental margin: a model. Geol. Soc. Am. Bull 86, 610-614.

Mosher, D.C., Erbacher, J., Malone, M.J., 2007. Proceedings of the Ocean Drilling Program, Scientific Results 207 : College Station, TX (Ocean Drilling Program). Mourges, R., Cobbold, P.R., 2003. Some tectonic consequences of fluid overpressures and seepage forces as demonstrated by sandbox modelling. Tectonophysics 376, 75-97.

Mourgues, R., Lecomte, E., Vendeville, B., Raillard, S., 2009. An experimental investigation of gravity-driven shale tectonics in progradational delta. Tectonophysics 474, 643-656.

Mulder, T., Cochonnat, P., 1996. Classification of offshore mass movements. Journal of Sedimentary Research 66, 43-57.

O’Regan, M., Moran, K., 2007. 15 . Compressibility, permeability, and stress history of sediments from demerara rise. Proceedings of the Ocean Drilling Program 207, 1-35. 
Parsiegla, N., Stankiewicz, J., Gohl, K., Ryberg, T., Uenzelmann-Neben, G., 2009. Southern African continental margin: Dynamic processes of a transform margin. Geochemistry, Geophysics, Geosystems 10, 20.

Pattier, F., Loncke, L., Gaullier, V., Vendeville, B., Maillard, A., Basile, C., Patriat, M., Roest, W.R., Loubrieu, B., 2011. Mass Movements in a Transform Margin Setting: The Example of the Eastern Demerara Rise, in: Yamada, Y., Kawamura, K., Ikehara, K., Ogawa, Y., Urgeles, R., Mosher, D., Chaytor, J., Strasser, M. (Eds.), Submarine Mass Movements and Their Consequences. Springer Netherlands, Dordrecht, pp. 331-339.

Pilcher, R., Argent, J., 2007. Mega-pockmarks and linear pockmark trains on the West African continental margin. Marine Geology 244, 15-32.

Plaza-Faverola, A., Bünz, S., Mienert, J., 2010. Fluid distributions inferred from Pwave velocity and reflection seismic amplitude anomalies beneath the Nyegga pockmark field of the mid-Norwegian margin, Marine and Petroleum Geology $27,46-60$.

Pujos, M., Froidefond, J., 1995. Water masses and suspended matter circulation on the French Guiana continental shelf. Continental Shelf Research 15, 11571171.

Reiche, S., Hjelstuen, B.O., Haflidason, H., 2011. High-resolution seismic stratigraphy, sedimentary processes and the origin of seabed cracks and pockmarks at Nyegga, mid-Norwegian margin. Mar. Geol. doi:10.1016/j.margeo.2011.03.006

Tryon, M.D., Henry, P., Çağatay, M.N., Zitter, T.A.C., Géli, L., Gasperini, L., Burnard, P., Bourlange, S., and Grall, C., 2010. Pore fluid chemistry of the North Anatolian Fault Zone in the Sea of Marmara: A diversity of sources and 
processes. Geochem. Geophys. Geosys., 11:Q0AD03. doi:10.1029/2010GC003177

Schmitz, W.J., McCartney, M.S., 1993. On the North Atlantic Circulation. Reviews of Geophysics 31, 29-49.

Séranne, M., 1999. Early Oligocene stratigraphic turnover on west Africa continental margin: signature of the Tertiary greenhous to icehous transition? TERRA NOVA 11, 135-140.

Geological Society of America 40, 439-442.

Stommel, H., Arons, A., 1959. On the abyssal circulation of the world ocean-I. Stationary planetary flow patterns on a sphere. Deep Sea Research 1953 6, 140-154.

Unternehr, P., Curie, D., Olivet, J.L., Goslin, J., Beuzart, P., 1988. South Atlantic fits and intraplate boundaries in Africa and South America. Tectonophysics 155, $169-179$.

Wagner, T., Pletsch, T., 1999. tecctono-sedimentary controls on Cretaceous black shale deposition along the opening Equatorial Atlantic Gateway (ODP Leg 159), in: CAMERON, N.R., BATE, R.H., CLURE, V.S. (Eds.), The Oil and Gas Habitats of the South Atlantic. Geological Society, London, Special Publications, 153. pp. $241-265$.

Zitter, T. a. C., Henry, P., Aloisi, G., Delaygue, G., Çagatay, M.N., Mercier de Lepinay, B., Al-Samir, M., Fornacciari, F., Tesmer, M., Pekdeger, A., Wallmann, K., Lericolais, G., 2008. Cold seeps along the main Marmara Fault in the Sea of Marmara (Turkey). Deep Sea Research Part I: Oceanographic Research Papers 55, 552-570. 


\section{Figure captions}

Figure 1: A. Location of the French Guiana margin. The directions of the main deep currents, that may interact with seafloor sedimentation are indicated by red dotted arrows. The transform segments of the margin are underlined by black arrows. B. Reconstruction of the central Atlantic during Albian time (Gouyet, 1988).

Figure 2: Interpretative geological section of the French Guiana margin (modified from Gouyet, 1988).

Figure 3: Seismic units on GUYAPLAC seismic line 63 (Vertical Exaggeration: 3). The stratigraphy is correlated to Well G2 (Gouyet 1988) and ODP leg 207 (see location in Figure 3) (Modified from Basile et al., 2012).

Figure 4: A. Multibeam bathymetric map; B. Dip map of the seafloor; C. Morphostructural map (See text for details); D. Bathymetric profile located in red in Figure 5.A

Figure 5: Tracklines of GUYAPLAC survey along the Demerara plateau. Location of seismic lines and $3.5 \mathrm{kHz}$ profiles shown in Figures 4, 9-11 and 13-14, and location of Well G2 (Gouyet 1988) and ODP leg 207 (Mosher et al., 2007)

Figure 6: A. Internal architecture of the Cenozoic sedimentary cover on GUYAPLAC seismic line 01 (Vertical Exaggeration 6) (see location on Figure 3) (insets indicate detailed view shown in Figure 11.B, C and D); MTDs are indicated by colored packages; B. Maximal depth map in ms twtt of the Upper Albian unconformity. C. 
Isopach map in meters (considering a mean overburden seismic velocity of $2 \mathrm{~km} / \mathrm{s}$ ) for the post-unconformity sedimentary cover.

Figure 7: Mass failure complex. A. Mass failure complex on the plateau and the abyssal plain (line 05; Vertical exaggeration 8; see location Figure 3). B; Isopach map of the mass failure complex in meters (assuming a mean seismic velocity of $2 \mathrm{~km} / \mathrm{s}$.

Figure 8: MTDs of mass failure complex. A. MTD distribution map. B. Detail on the failure scar (GUYAPLAC line 01) (MTDs are colored according to the main legend); C. MTD zoom of the intermediate plateau (GUYAPLAC line 01) (MTDs are colored according to the main legend); D. MTD close-up of the lower plateau (line 01) (MTDs are colored according to the main legend).

Figure 9: Isopach map of the post-MTDs sediments in meters considering a mean seismic velocity of $2 \mathrm{~km} / \mathrm{s}$.

Figure 10: Fault families of the Demerara plateau on GUYAPLAC line 01 (Vertical Exaggeration $\times 12$; see location Figure 3)

Figure 11: Depressions observed on the seafloor of the Demerara plateau; $A$. Depression field in blue.; B. Detail of the bathymetry map; C. Detail of the reflectivity map; D. NW-SE bathymetric profile of the depression 5 (Red, location of high reflectivity); E. SW-NE bathymetric profile of the depression 5 (Red, location of high reflectivity); F. NW-SE bathymetric profile of depression 3 (Red, location of high reflectivity); 
Figure 12: Type A and Type B depressions of the Demerara plateau; A. $3.5 \mathrm{kHz}$ profile GUYAPLAC 22-23 (Vertical exaggeration $x$ 15); B. 83-5 kHz profile GUYAPLAC 28-29 (Vertical exaggeration x 22); C. Seismic profile GUYAPLAC 22-23 (MTD 04, in green) (Vertical exaggeration x 8); D. Seismic profile GUYAPLAC 28-29 (MTD 04, in green; MTD 10, in white; MTD 12, in brown) (Vertical exaggeration x8); see locations on Figure 3 and Figure 7.B.

Figure 13: Frequency histogram of slope values of the northwestern flank referred to as NW slope within type B elongate depressions.

Figure 14: Type B depressions of the Demerara plateau; A. 3-5 kHz profile GUYAPLAC 25-26 (Vertical exaggeration x 15); B. Seismic profile GUYAPLAC 25-26 (MTD 04, green, and MTD 12, brown) (Vertical exaggeration x 8);. See location in Figures 3 and 7.B

Figure 15: Schematic geometry of type A and type B depressions.

Figure 16: Schema summarizing possible fluid origins and pathways to the surface.

Figure 17: Evolutionary scenario for the Demerara plateau since the upper Albian. 


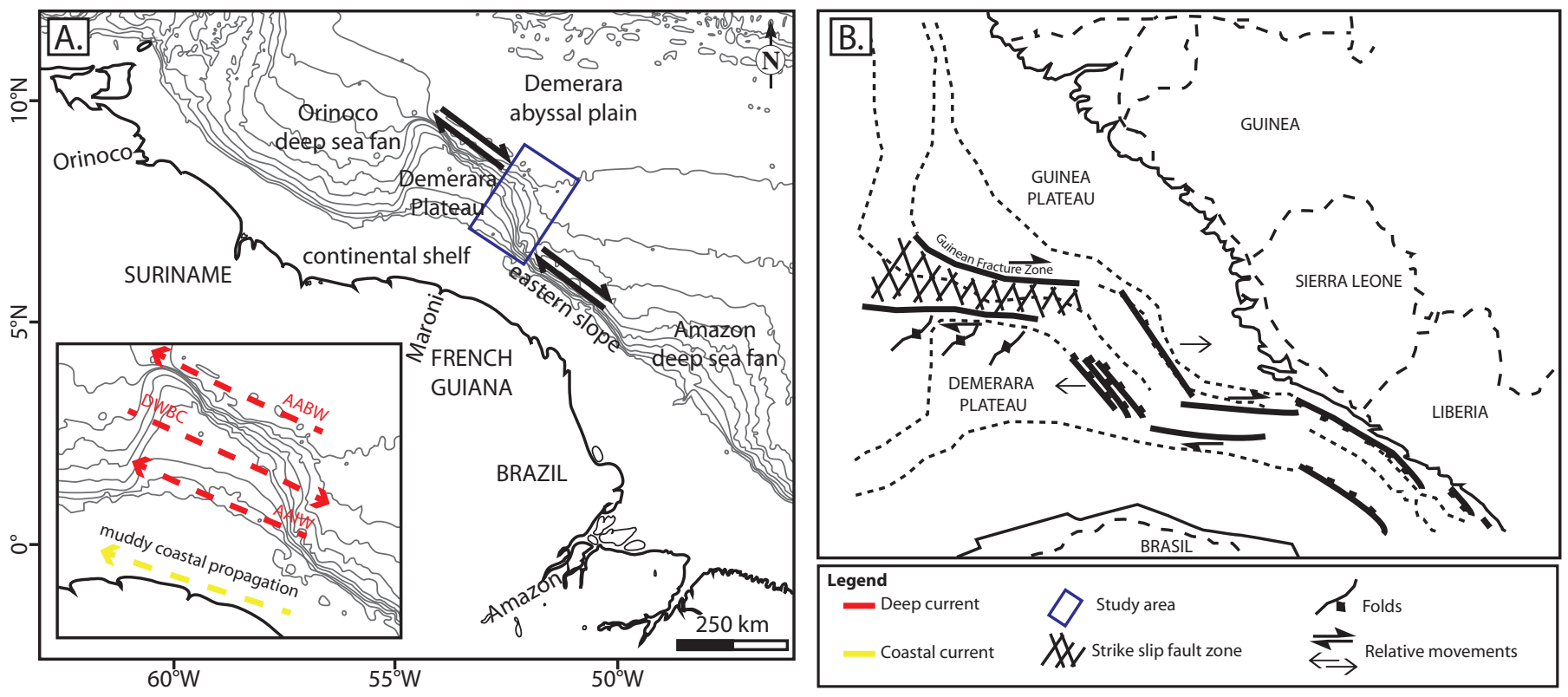




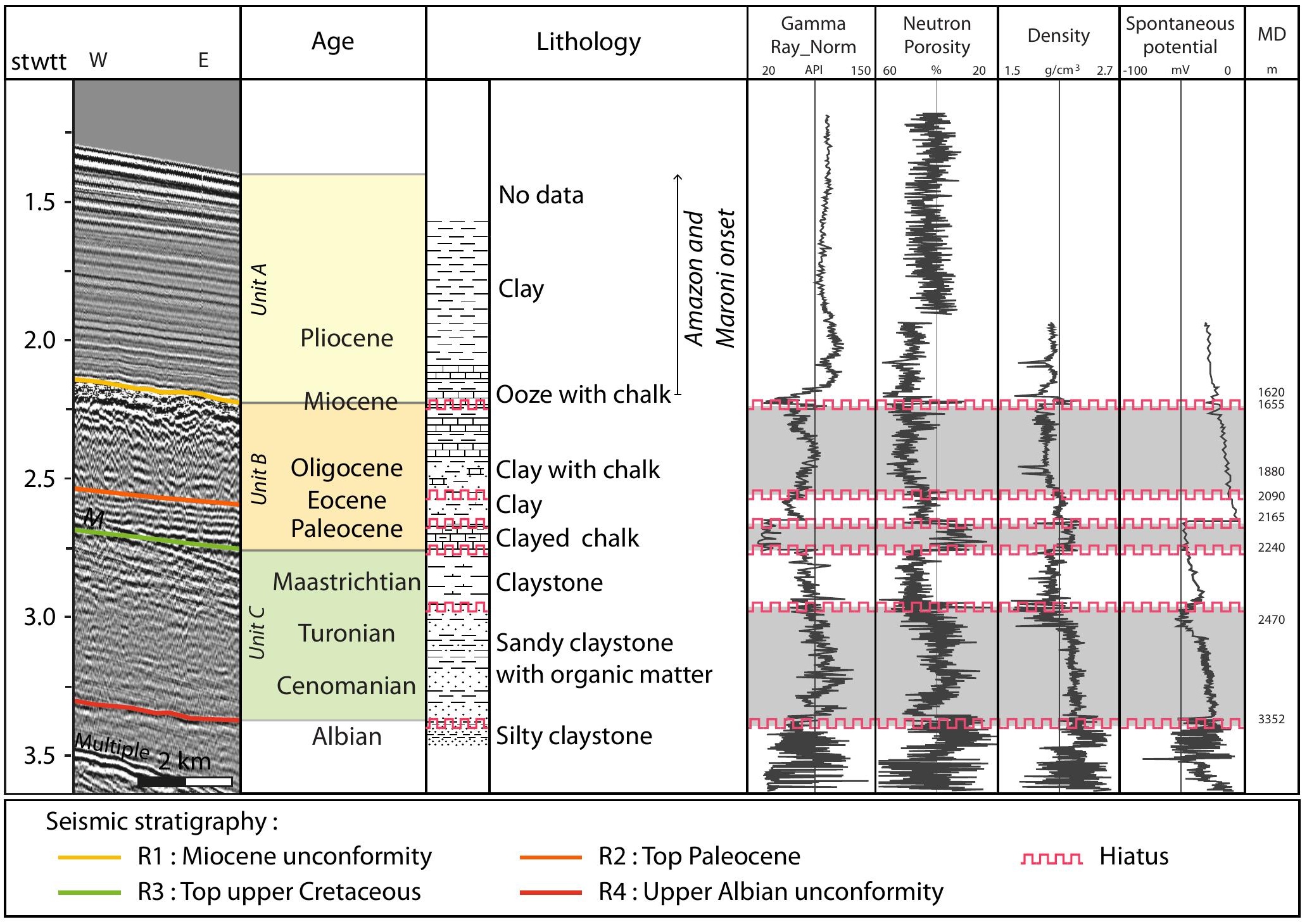




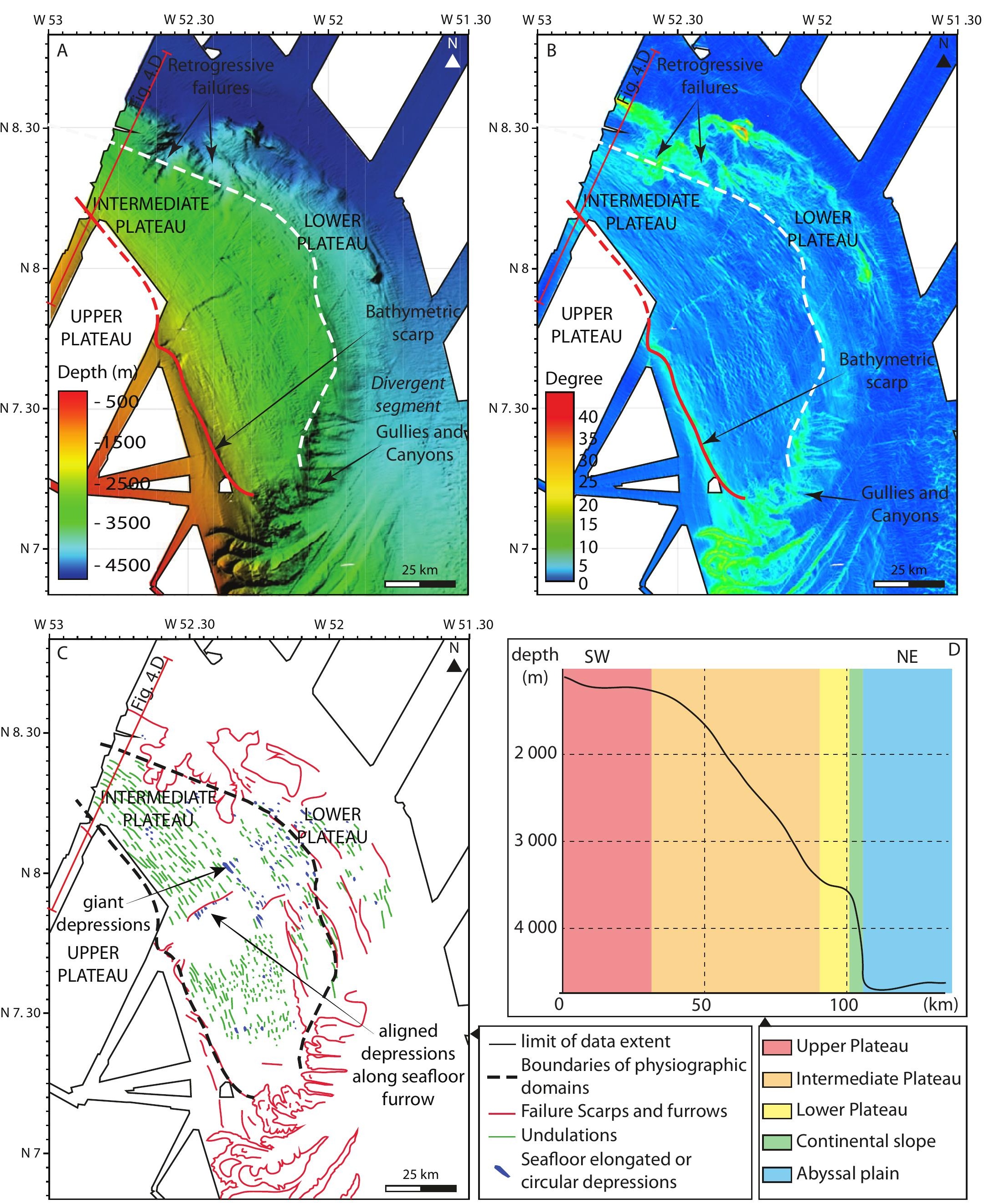



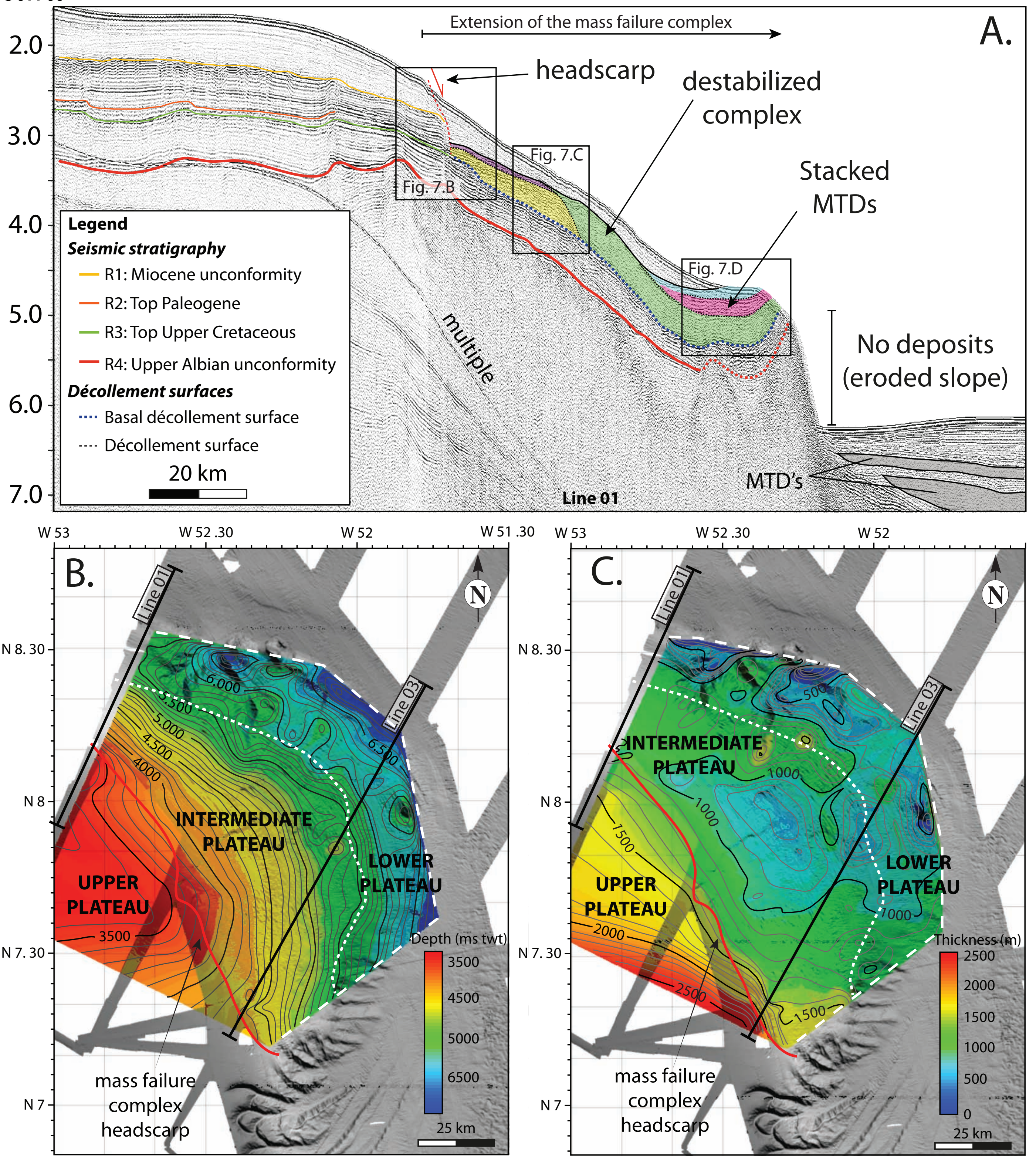


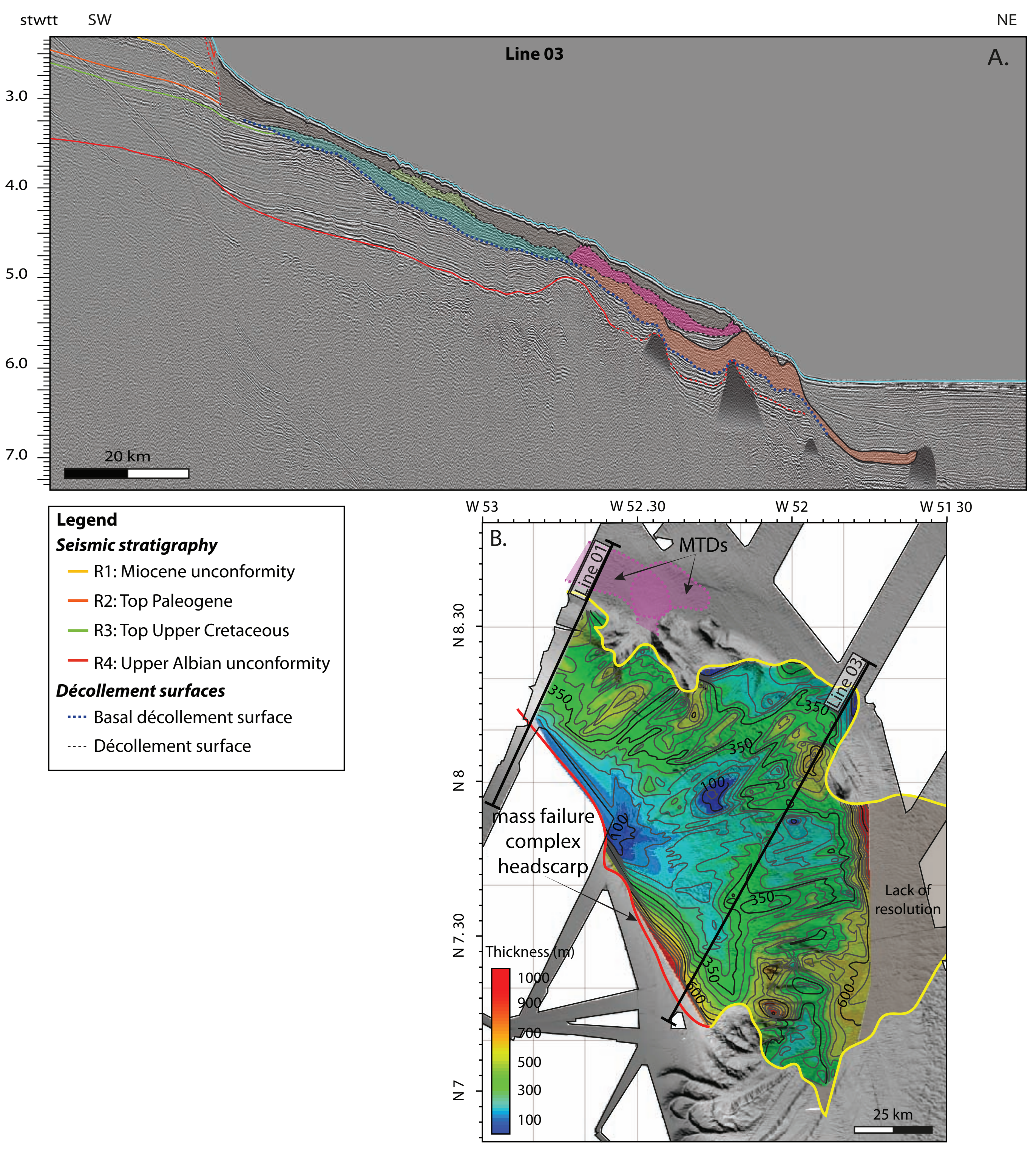




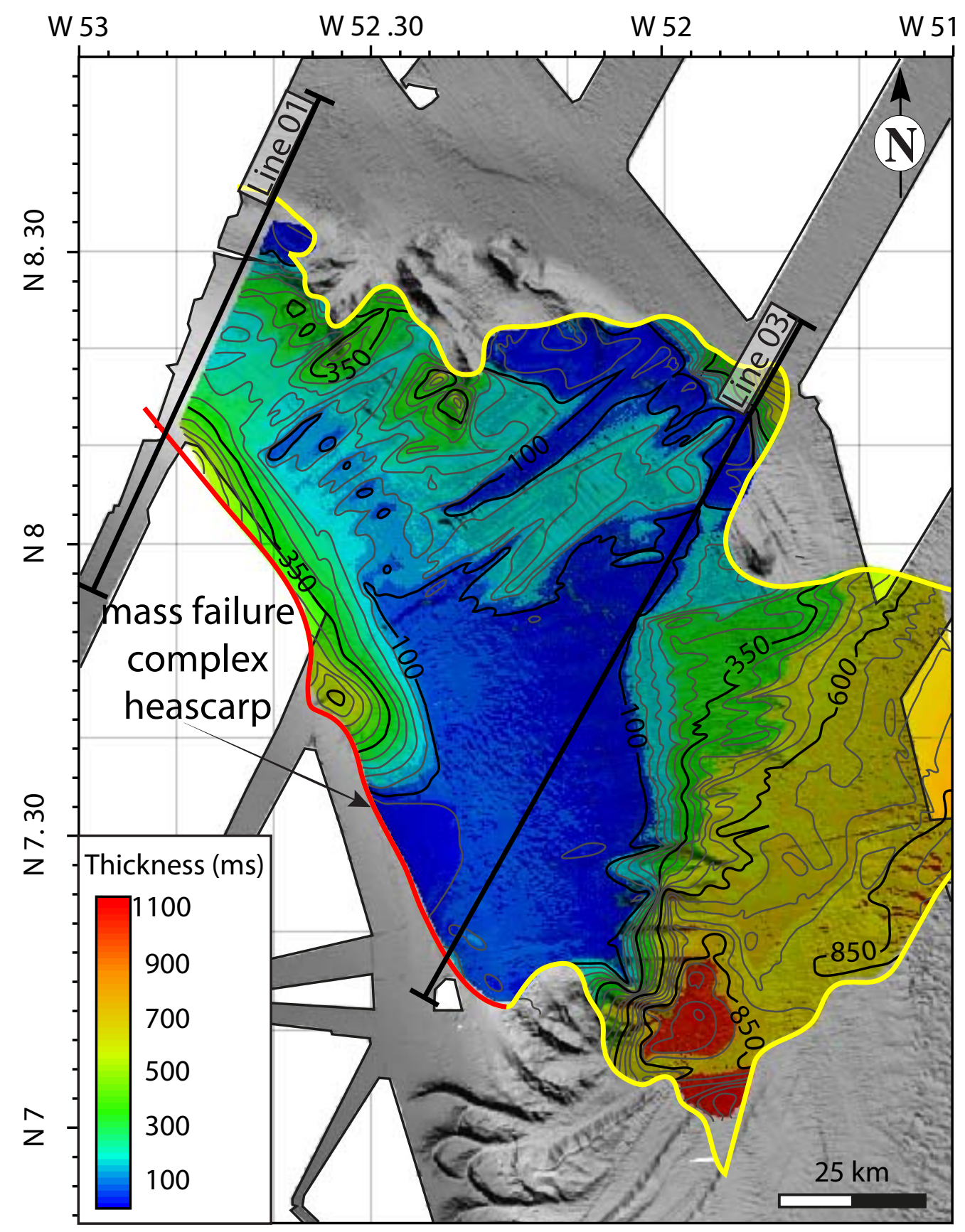




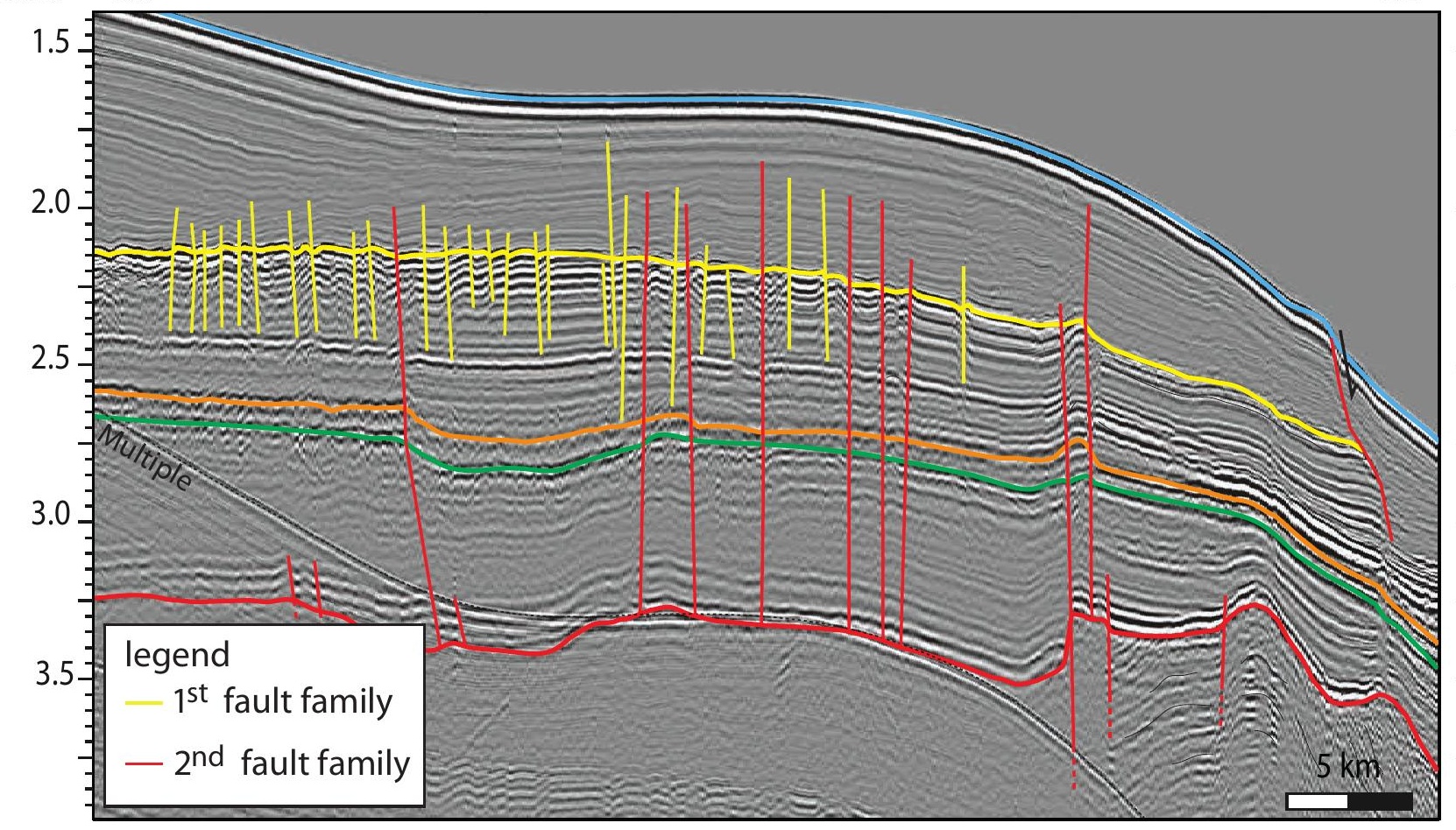




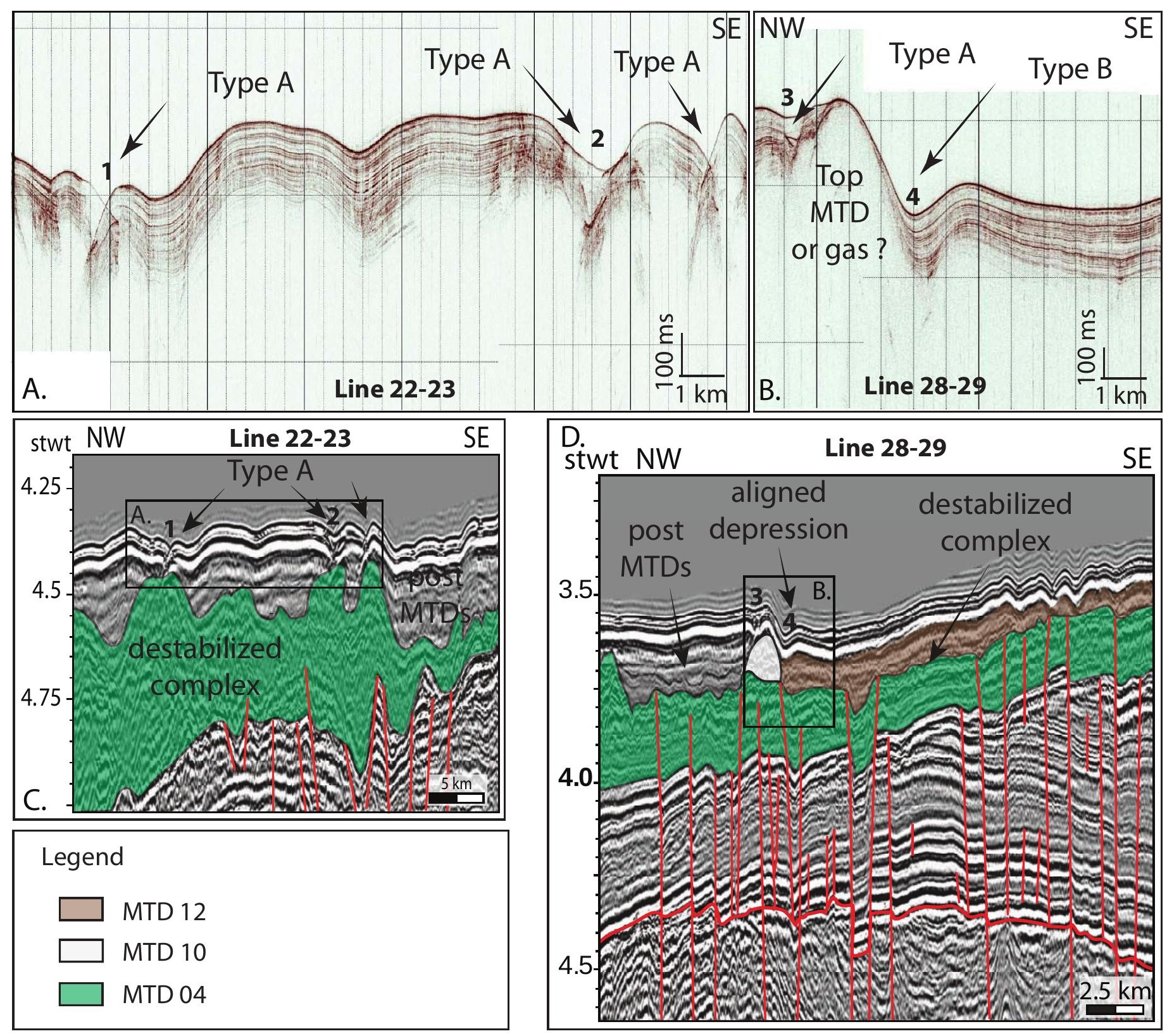




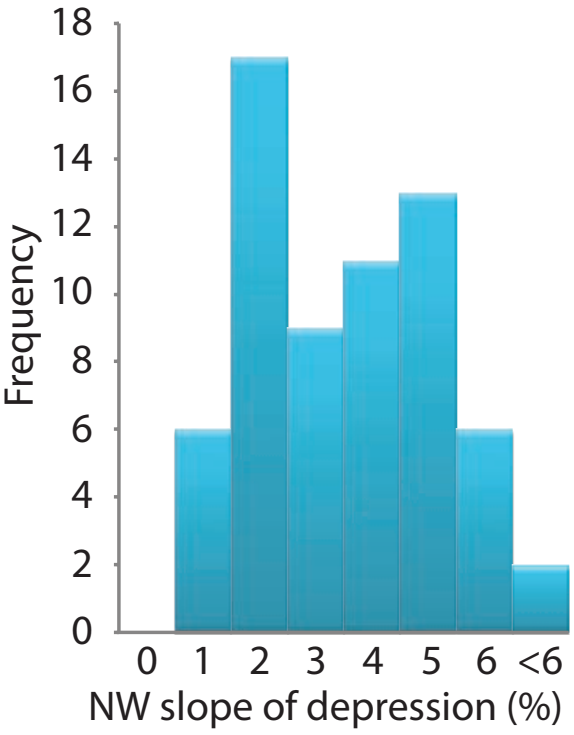




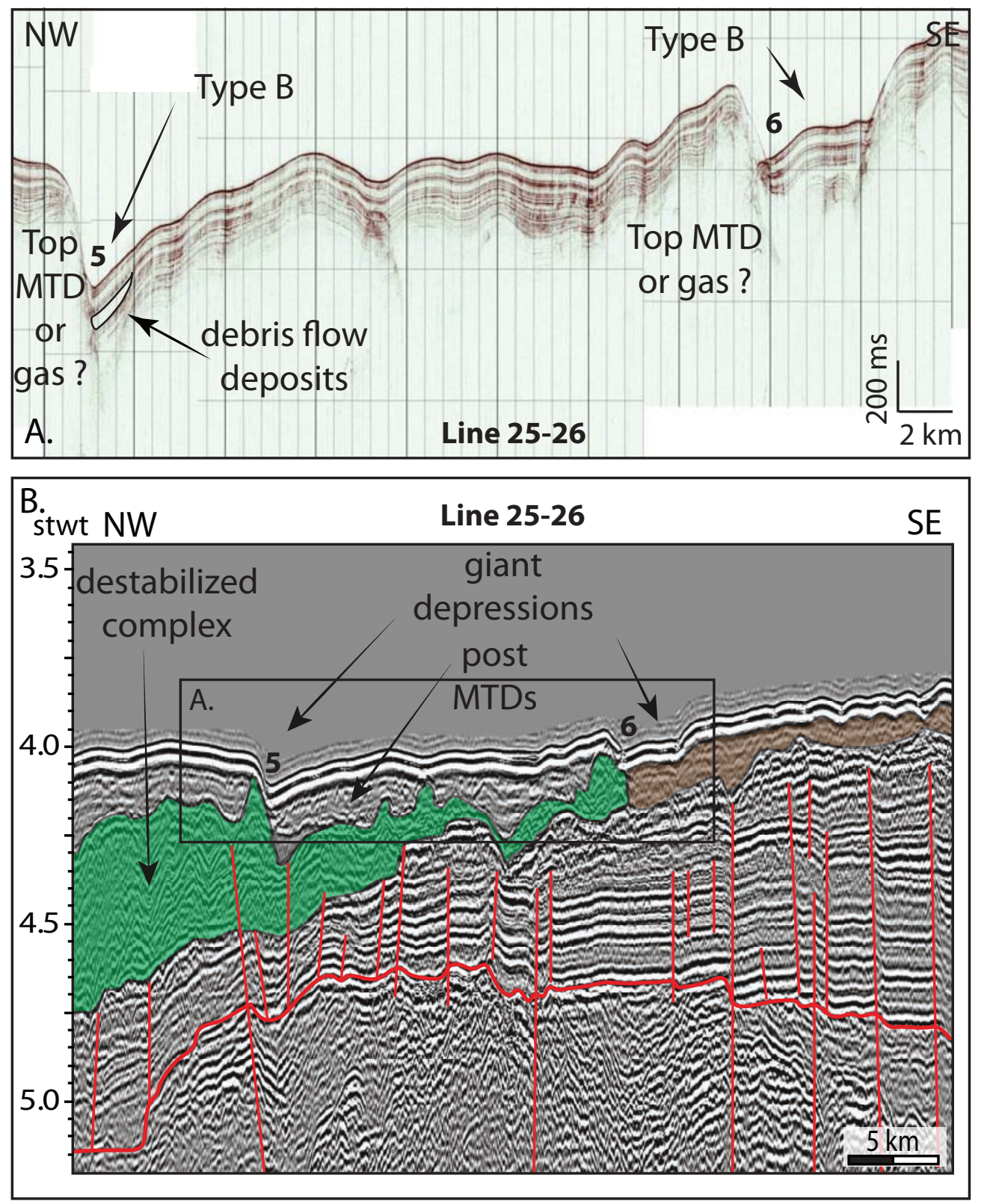


Type A

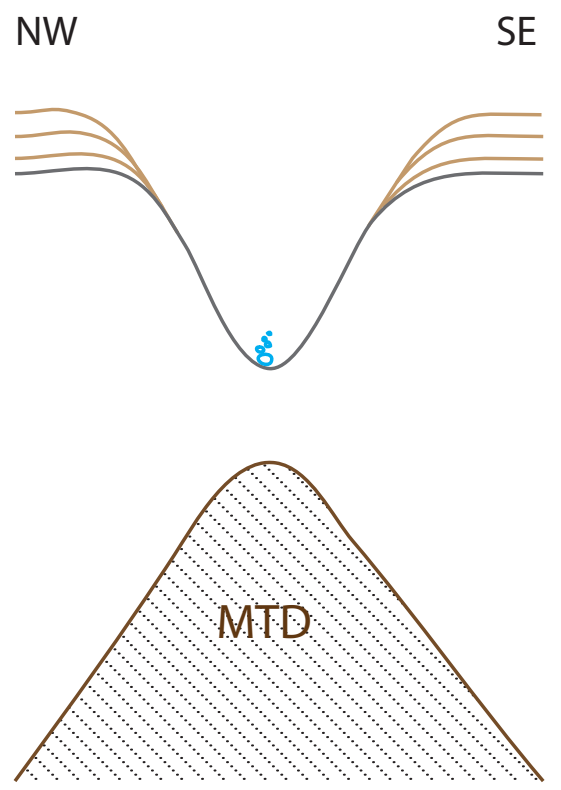

Type B

NW

SE 


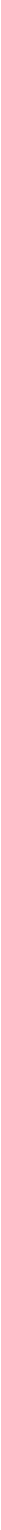




\section{Schematic reconstruction of the evolution of the margin}

\section{Albian erosion (syn-transform unconformity)}

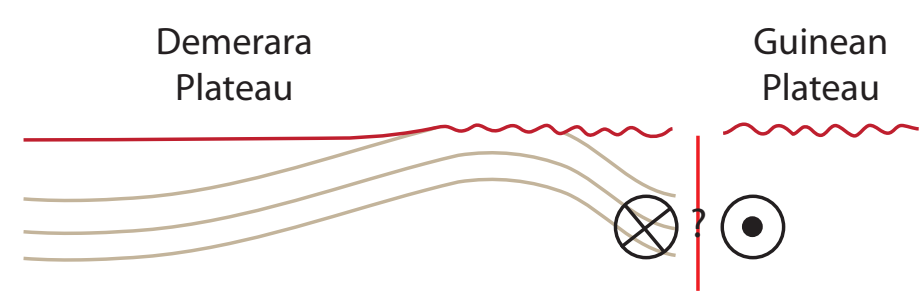

\section{Upper Cretaceous sediment deposition}

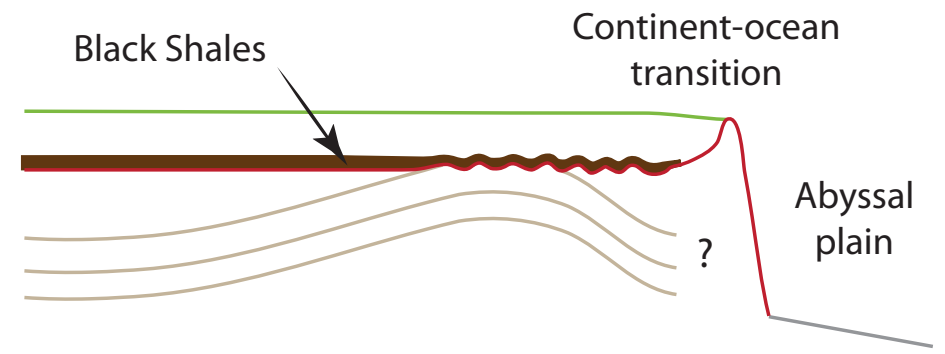

3. Cenozoic oceanward tilting (Basile et al., 2013)

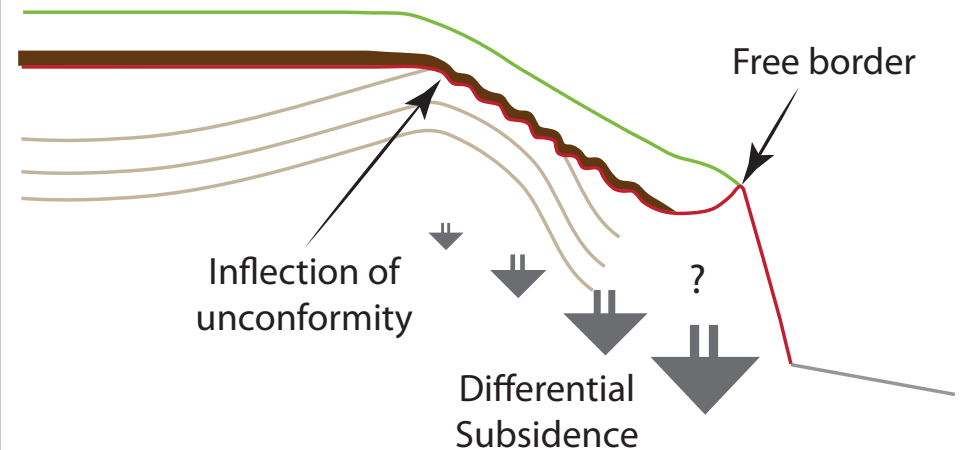

4. Paleogene sediment deposition and progressive compaction with development of polygonal fault system

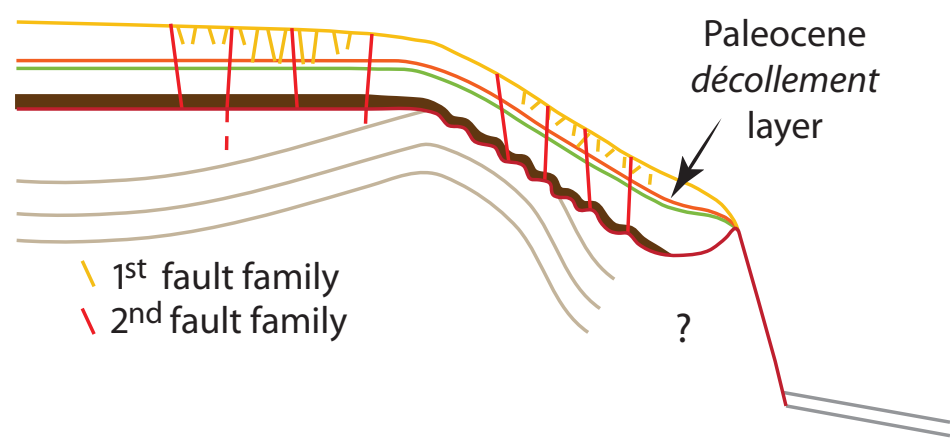

\section{Gravity destabilisation}

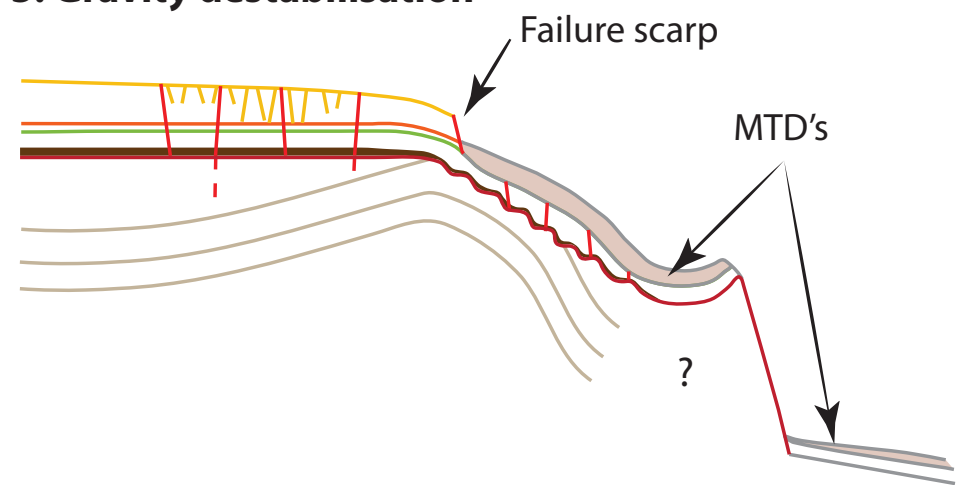

6. Neogene progradation

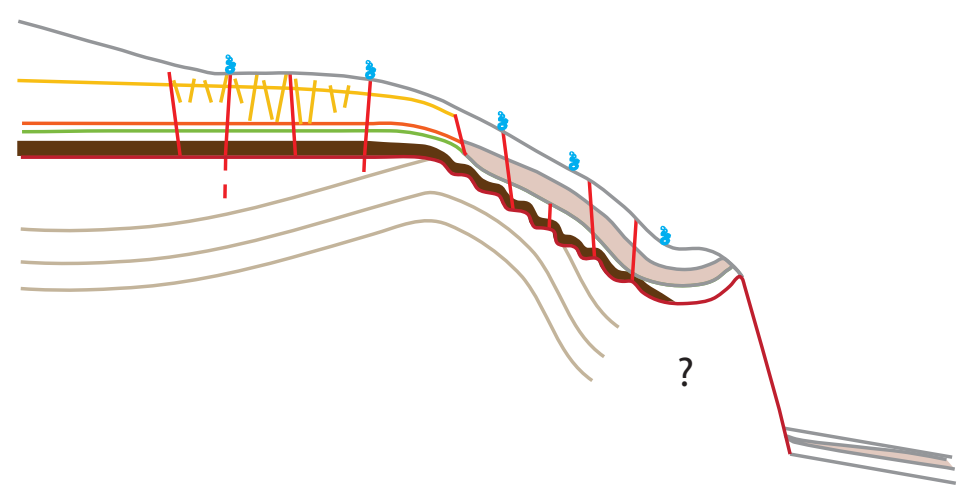

7. Neogene slope instabilities

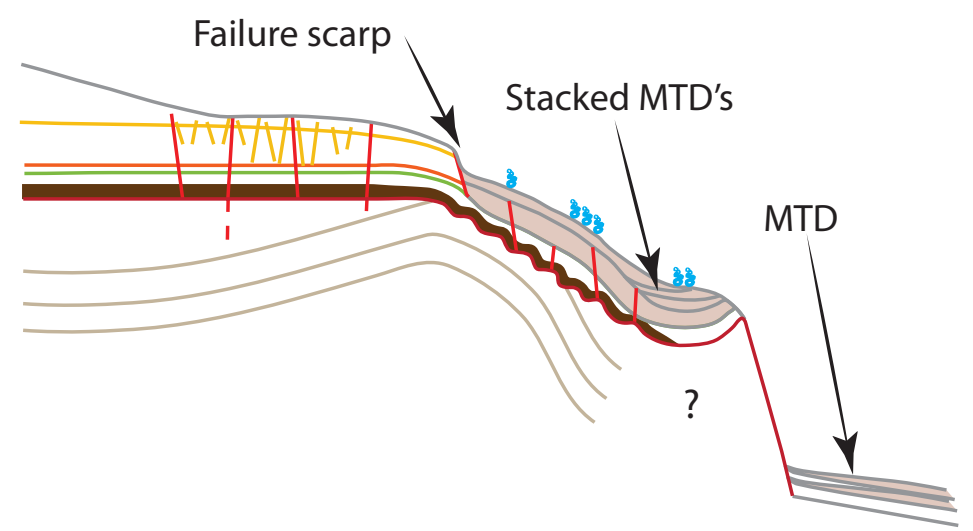

8. Quaternary developement of pockmarks and ridges Recent

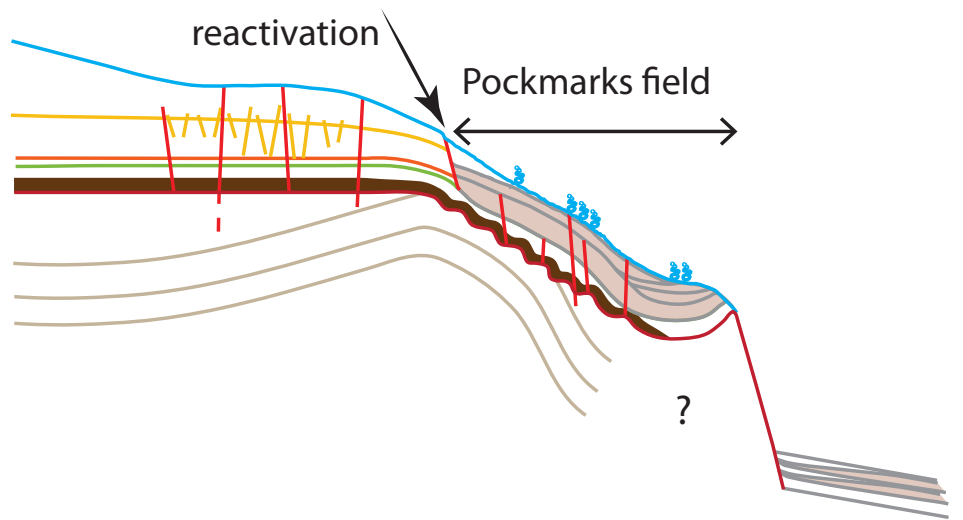

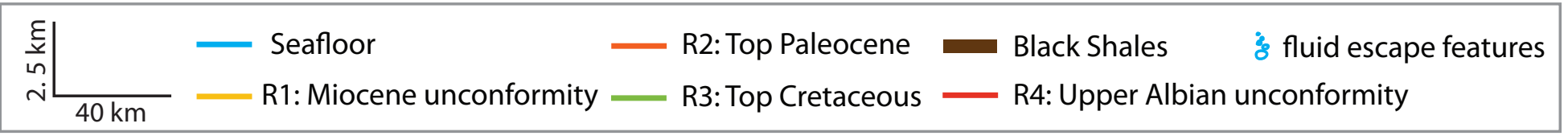

